\title{
Holocene tephrochronology of the lower Río Cisnes valley, southern Chile
}

\author{
Derek J. Weller'1, María Eugenia de Porras², Antonio Maldonado ${ }^{2,3,4}$, \\ César Méndez ${ }^{5}$, Charles R. Stern ${ }^{1}$
}

\author{
${ }^{I}$ Department of Geological Sciences, University of Colorado, Boulder, Colorado, 80309-0399, USA. \\ Derek.Weller@colorado.edu; Charles.Stern@colorado.edu \\ 2 Centro de Estudios Avanzados en Zonas Áridas (CEAZA), Instituto de Investigación Multidisciplinario en Ciencia y Tecnología, \\ Universidad de La Serena, Avda. Raúl Bitrán 1305, La Serena, Chile. \\ meugenia.deporras@ceaza.cl \\ 3 Departamento de Biología Marina, Universidad Católica del Norte, Larrondo 1281, Coquimbo, Chile. \\ amaldona@userena.cl \\ ${ }_{4}^{4}$ Instituto de Investigación Multidisciplinario en Ciencia y Tecnología, Universidad de La Serena, Avda. Raúl Bitrán 1305, la Serena, Chile. \\ 5 Centro de Investigación en Ecosistemas de la Patagonia (CIEP), Almirante Simpson 471, Coyhaique, Chile. \\ cesar.mendez@ciep.cl
}

\begin{abstract}
Sediment cores from lakes and bogs in the Río Cisnes valley contain tephra from explosive eruptions of volcanoes in the southern part of the Andean Southern Volcanic Zone (SSVZ). These tephra, which thicken and coarsen to the west, are attributed to eruptions from Melimoyu, Mentolat, Hudson, and potentially either Macá, Cay or one of the many minor eruptive centers (MEC) located both along the Liquiñe-Ofqui Fault Zone (LOFZ) and surrounding the major volcanoes. Correlation of the tephra between two new cores in the lower Río Cisnes valley, and amongst other cores previously described from the region, and source volcano identification for the tephra, has been done using lithostratigraphic data (tephra layer thickness and grain size), petrography (tephra glass color, vesicle morphology, and type and abundance of phenocryst phases), and by comparison of bulk tephra trace-element characteristics with previously published whole-rock and bulk tephra chemical analysis. Four tephras in these cores are attributed to eruptions of Mentolat, four to eruptions from Melimoyu, one possibly to Hudson, and six cannot be assigned to a specific source volcano. Some of these tephra correspond to pyroclastic tephra fall deposits previously observed in outcrop, including the MEL2 eruption of Melimoyu and the MEN1 eruption of Mentolat. However, others have not been previously observed and represent the products of newly identified small to medium sized eruptions from volcanoes of the SSVZ. These results provide new information concerning the frequency and magnitude of explosive eruption of SSVZ volcanoes and contribute to the evaluation of volcanic hazards in the region.
\end{abstract}

Keywords: Andean volcanism, Tephra, Tephrochronology, Chile.

RESUMEN. Tefrocronología holocena del curso inferior del valle de río Cisnes, Chile austral. Los testigos de sedimentos de lagos y pantanos obtenidos en el valle del río Cisnes contienen niveles de tefra originados por erupciones explosivas de volcanes localizados en la parte sur de la Zona Volcánica de los Andes del Sur (SZVS). Estos depósitos de tefra, que aumentan de espesor y tamaño del grano hacia el oeste, son atribuidos a erupciones de los volcanes Melimoyu, Mentolat, Hudson y potencialmente a los volcanes Macá, Cay o alguno de los numerosos centros eruptivos menores (CEM) localizados a lo largo de la Zona de Falla Liquiñe-Ofqui (ZFLO) y que rodean a los volcanes principales. La correlación de los niveles de tefra identificados en dos nuevos testigos, obtenidos en el curso inferior del valle del río Cisnes, con aquellos presentes en testigos descritos con anterioridad en la región y la identificación de los volcanes fuente de las tefras, se realizó con la ayuda de datos litoestratigráficos, (espesor de la capa de tefra y tamaño del grano), petrografía (color de los fragmentos de vidrio, morfología de las vesículas y tipo y abundancia de fenocristales) y por comparación de sus patrones de elementos trazas con análisis químicos de roca total y tefra total publicados con anterioridad. Cuatro niveles de tefras identificados en estos nuevos testigos se atribuyen a erupciones del volcán Mentolat, otros cuatro se asignan al volcán Melimoyu y uno, posiblemente, fue originado por el volcán Hudson. Otros seis no pueden ser asignados a un volcán específico. Algunas de estas tefras corresponden a depósitos de tefras observados previamente en afloramientos, asignados a las erupciones MEL 2 del volcán Melimoyu y MEN 1 del volcán Mentolat. Sin embargo, otros niveles de tefra no han sido reconocidos previamente y representan los productos de erupciones de tamaño pequeño a mediano de los volcanes de la SZVS recientemente identificadas en este trabajo. Estos resultados proporcionan nueva información sobre la frecuencia y magnitud de las erupciones explosivas de los volcanes de la SZVS y contribuyen a la evaluación de los peligros volcánicos en la región. 


\section{Introduction}

Tephra produced by explosive eruptions can disperse over large distances in a very short period of time. Once characterized chemically, physically and morphologically, tephras provide chronological time horizons, or isochrones, that can be correlated from one locality to the next (Lowe, 2011; Fontijn et al., 2014). Tephras deposited in lakes and bogs preserve exceptional records of volcanic activity (Weller et $a l ., 2015)$, which provide insight into the frequency and magnitude of explosive eruptions, because of the relatively continuous record of sedimentation in these depositional environments.

Two recently retrieved cores from the lower Río Cisnes valley (Fig. 1), one from Laguna Las Mellizas (LLM) and one from Laguna Junco (LJU; Fig. 2), contain a record of tephra deposits derived from volcanoes of the southernmost part of the Andean Southern Volcanic Zone (SSVZ). Based on radiocarbon dating of organic matter from near the base of these cores (Table 1), where the lithology transitions upwards from finely-laminated glacial-lacustrine clays and fine-grained sands to predominately organic matterrich material (Fig. 2), and from other lake cores taken from the region (De Porras et al., 2012, 2014; Stern et al., 2015), the present day lacustrine system was established at least by $\sim 12,230$ cal years BP, the deepest dated layer in the LLM core (Fig. 2; Table 1), following retreat of the mountain glaciers from the region (Miranda et al., 2013). Since glacial retreat, numerous tephras were deposited within these two small lakes, each with limited drainage catchments. Here, we use the bulk trace-element chemistry, lithostratigraphic data (tephra thickness and grain size), and petrographic features to characterize each tephra, to identify potential source volcanoes, and correlate these deposits with other tephra previously identified in both outcrops and in other lake cores from the region (Naranjo and Stern, 2004; Stern et al., 2015, 2016; Weller et al., 2014, 2015).

\section{Geologic Background}

The Andean Southern Volcanic Zone (SVZ; Fig. 1), a volcanic chain stretching from $33^{\circ} \mathrm{S}$ to $46^{\circ} \mathrm{S}$ in Chile and Argentina, is generated by the subduction of the Nazca oceanic plate beneath the South American continent (Stern, 2004). The southern end of this zone is defined by the subduction of the Chile Rise, an active spreading center separating the Nazca and Antarctic Plates. This study is focused on the southernmost part of the SVZ, specifically the five large volcanic centers Melimoyu, Mentolat, Macá, Cay and Hudson, as well as numerous monogenetic minor eruptive centers (MEC) located along the Liquiñe-Ofqui Fault Zone (LOFZ) or surrounding Macá, Cay, and Hudson (Fig. 1; López-Escobar et al., 1993, 1995a; D’Orazio et al., 2003; Gutiérrez et al., 2005).

Melimoyu, which has a larger than average edifice compared to other SVZ centers $\left(\sim 142 \mathrm{~km}^{3}\right.$; Völker et al., 2011), is constructed of basalt, andesite and dacite lava flows (López-Escobar et al., 1993) with a small $1 \mathrm{~km}$ wide summit crater (Naranjo and Stern, 2004). Two Holocene tephras (MEL1 and MEL2) observed in outcrops directly east of the volcano (Naranjo and Stern, 2004) and in lake cores in the upper Río Cisnes valley southeast of the volcano (Stern et al., 2015), have been attributed to explosive eruptions from Melimoyu volcano. They have been dated at 2,765 \pm 70 and $1,680 \pm 80$ cal years $\mathrm{BP}$, respectively. Stern et al. (2015) also identified a number of other Holocene and one late-glacial tephra derived from Melimoyu in a core from Lago Shaman and an outcrop in the upper valley of the Río Cisnes (Fig. 1).

Mentolat volcano, which is a relatively small edifice ( $\sim 36 \mathrm{~km}^{3}$; Völker et al., 2011), with a snow and ice covered dome filling a summit caldera (Naranjo and Stern, 2004), is formed of basaltic andesite and andesitic lava flows (López-Escobar et al., 1993). Naranjo and Stern (2004) observed a light gray andesitic tephra (MEN1) in outcrops to the southeast of the volcanic center which has been dated at 7,690 \pm 60 cal years BP (Stern et al., 2016), and Mella et al. (2012) described a younger tephra (MEN-1; not the same as the MEN1 of Naranjo and Stern, 2004) from near Puerto Cisnes which have been dated as $>2,614 \pm 87$ and $4,336 \pm 56$ cal years BP. Additionally, a late-glacial (MENo) and many other Holocene tephras derived from Mentolat, including MEN1, have been documented in lake cores from Lago Shaman and Mallín El Embudo (Fig. 1; Stern et al., 2015) in the upper Río Cisnes valley and from lake cores near Coyhaique (Weller et al., 2014, 2015) and Cochrane (Stern et al., 2016).

Macá and Cay are both also relatively small centers ( $\sim 39$ and $\sim 49 \mathrm{~km}^{3}$ respectively; Völker et al., 2011). Macá is formed of basalt and basaltic andesite lavas 


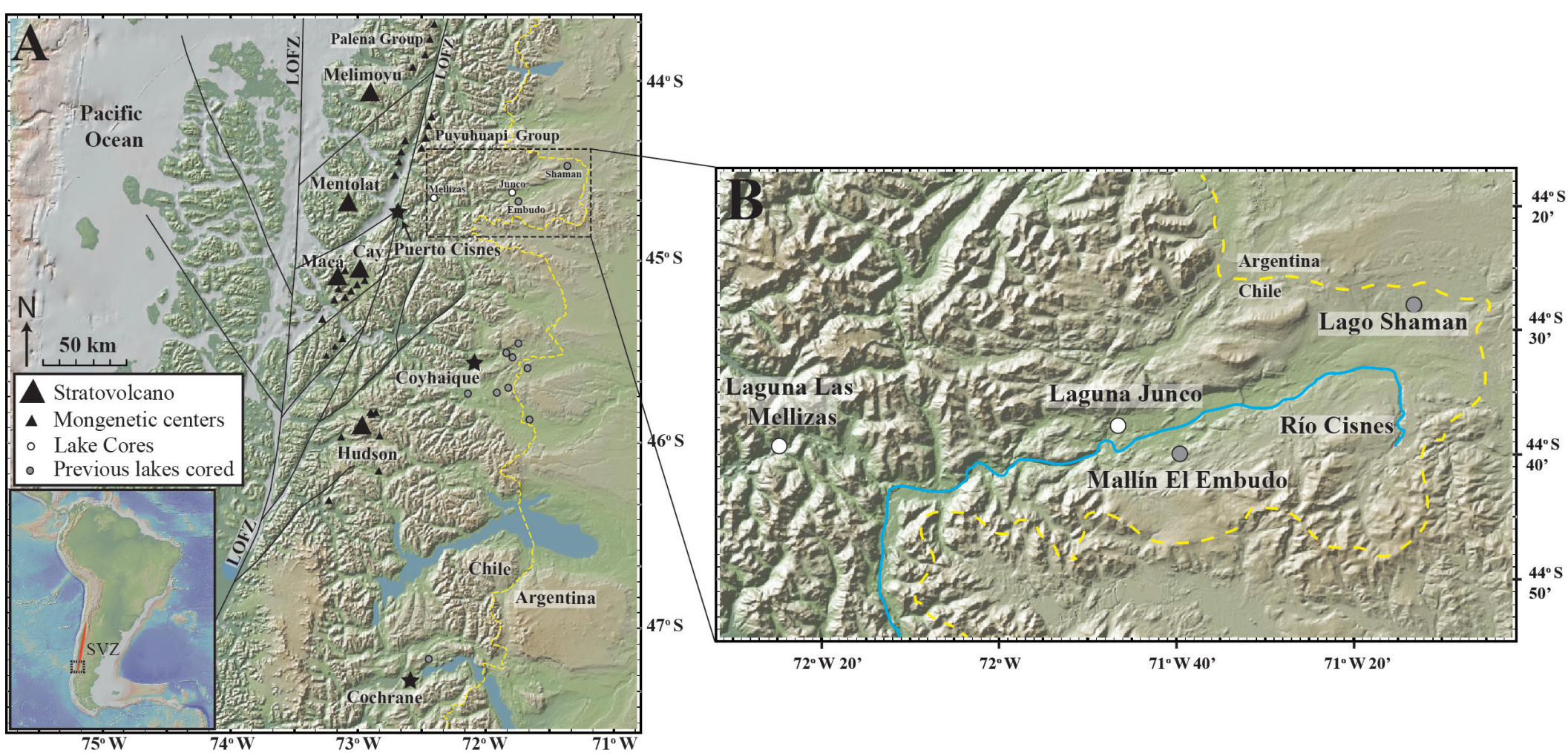

FIG. 1. A. Map showing the location of Laguna Las Mellizas (LLM) and Laguna Junco (LJU) from which tephra bearing cores were obtained and the location of the major volcanic centers of the southern part of the Andean Southern Volcanic Zone (SSVZ) and minor eruptive centers (MEC) located along the Liquiñe-Ofqui fault zone (LOFZ) and surrounding Hudson (Gutiérrez et al., 2005; Vargas et al., 2013), Macá, and Cay (López-Escobar et al., 1995a; D’Orazio et al., 2003); B. Map of the Río Cisnes valley showing the location of LLM and LJU, and the location for other lakes from which tephra from SSVZ volcanoes have been previously reported (Lago Shaman and Mallín El Embudo; De Porras et al., 2012, 2014; Stern et al., 2015). 


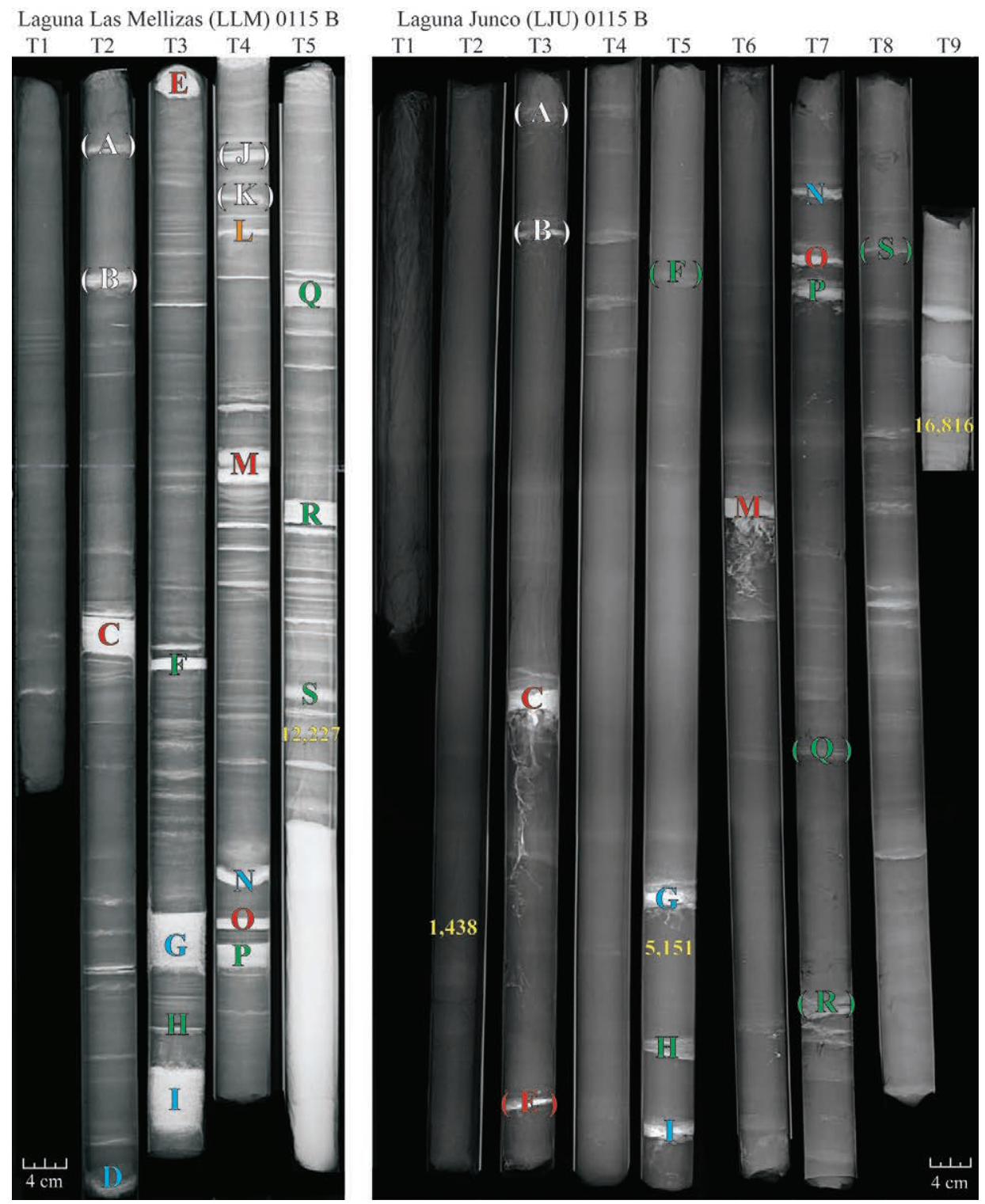

FIG. 2. X-ray photograph of the $\sim 5.51$ meter sections of the core from LLM $(0115 \mathrm{~B})$ and the $\sim 7.51$ meter sections core form LJU (0115 B). The tephra layers are white because they are denser lithologies than the organic matter-rich sediments they are preserved within. Sampled and unsampled (parentheses) tephras are labeled A thought $\mathrm{S}$ and are color coded based on the petrochemical type (red: high abundance (HA), green: low abundance (LA), and blue: very low abundance (VLA)). Also shown are the location and age of carbon-14 samples taken from the cores (yellow). Each core sections is approximately $1 \mathrm{~m}$ in length and $4 \mathrm{~cm}$ in diameter.

(Futa and Stern, 1988; López-Escobar et al., 1993; D'Orazio et al., 2003). One Holocene tephra observed in outcrop, MAC1 (Naranjo and Stern, 2004), and in lake cores from near Coyhaique (tephra D3; Weller et al., 2015), has been attributed to a medium-sized eruption of this volcano dated at $1,440 \pm 40$ cal years
BP. Cay volcano is a highly eroded edifice which is constructed of basalts, basaltic andesites, and dacites. No previous observations of Holocene deposits have been attributed to this volcano and the highly eroded nature of this center suggests a quiescent eruptive history throughout the Holocene. 
TABLE 1. DEPTH IN CENTIMETERS (CM) OF TEPHRA AND ${ }^{14}$ C AGE DATES (CAL YR BP) FROM LAGUNA LAS MELLIZAS AND LAGUNA JUNCO CORES.

\begin{tabular}{|c|c|c|c|c|c|c|c|c|c|}
\hline \multirow{2}{*}{ Tephra } & \multicolumn{2}{|c|}{ LLM 0115 B } & \multicolumn{2}{|c|}{ LJU 0115 B } & \multirow{2}{*}{$\begin{array}{c}\text { Shaman } \\
\text { Tephra }\end{array}$} & \multirow{2}{*}{ Source } & \multirow{2}{*}{$\begin{array}{c}\text { Outcrop } \\
\text { Tephra }\end{array}$} & \multirow{2}{*}{ New Ages } & \multirow{2}{*}{ Other Ages } \\
\hline & Section & Depth (cm) & Section & Depth (cm) & & & & & \\
\hline- & - & - & $\mathrm{T} 2$ & $78-79$ & - & - & - & $1,438 \pm 24$ & - \\
\hline $\mathrm{C}$ & $\mathrm{T} 2$ & $46-49$ & $\mathrm{~T} 3$ & $53-55$ & $\mathrm{a}$ & Melimoyu & MEL2 ${ }^{1}$ & - & $<1,680^{1}$ \\
\hline $\mathrm{D}$ & $\mathrm{T} 2$ & $94-96$ & - & - & $\mathrm{c}$ & Mentolat & - & - & $2,490^{2}$ \\
\hline E & $\mathrm{T} 3$ & $0-3$ & - & - & - & Melimoyu & - & - & - \\
\hline F & $\mathrm{T} 3$ & $49.5-50$ & - & - & - & $\mathrm{M} / \mathrm{C} / \mathrm{M}$ & - & - & - \\
\hline $\mathrm{G}$ & $\mathrm{T} 3$ & $71-77$ & $\mathrm{~T} 5$ & $71-72$ & d & Mentolat & $\mathrm{MEN}-1^{3}$ & - & \\
\hline- & - & - & T5 & $82-83$ & - & - & - & $5,151 \pm 35$ & - \\
\hline $\mathrm{H}$ & - & - & T5 & $83.5-85$ & - & $\mathrm{M} / \mathrm{C} / \mathrm{M}$ & - & - & - \\
\hline I & $\mathrm{T} 3$ & $86-92$ & T5 & $92-93$ & $\mathrm{e}$ & Mentolat & - & - & \\
\hline $\mathrm{L}$ & $\mathrm{T} 4$ & $15-15.5$ & - & - & - & Hudson & - & - & - \\
\hline M & $\mathrm{T} 4$ & $33.5-34.5$ & T6 & $38-39$ & - & Melimoyu & - & - & - \\
\hline $\mathrm{N}$ & $\mathrm{T} 4$ & $67-68$ & $\mathrm{~T} 7$ & $10.5-11$ & $\mathrm{i}$ & Mentolat & MEN1 $^{1}$ & - & $7,690^{1}$ \\
\hline $\mathrm{O}$ & $\mathrm{T} 4$ & $71-72$ & $\mathrm{~T} 7$ & $16-16.5$ & - & Melimoyu & - & - & - \\
\hline $\mathrm{P}$ & $\mathrm{T} 4$ & $74-76$ & $\mathrm{~T} 7$ & $19-20$ & - & $\mathrm{M} / \mathrm{C} / \mathrm{M}$ & - & - & - \\
\hline Q & T5 & $19-21$ & - & - & - & $\mathrm{M} / \mathrm{C} / \mathrm{M}$ & - & - & - \\
\hline $\mathrm{R}$ & T5 & $35-37$ & - & - & - & $\mathrm{M} / \mathrm{C} / \mathrm{M}$ & - & - & - \\
\hline S & T5 & $51-52$ & - & - & - & $\mathrm{M} / \mathrm{C} / \mathrm{M}$ & - & - & - \\
\hline- & $\mathrm{T} 5$ & $56-57$ & - & - & - & - & - & $12,227 \pm 38$ & - \\
\hline - & - & - & T9 & $7-8$ & - & - & - & $16,816 \pm 68$ & - \\
\hline
\end{tabular}

${ }^{1}$ Naranjo and Stern, 2004; ${ }^{2}$ Stern et al., 2015; ${ }^{3}$ Mella et al., 2012.

Hudson is a larger than average SVZ volcano ( $\sim 147 \mathrm{~km}^{3}$; Völker et al., 2011), which has a $\sim 10 \mathrm{~km}$ wide summit caldera and is formed by lavas with a wide range of compositions including basalt, basaltic andesites, andesites, and dacites (Futa and Stern, 1988; Gutiérrez et al., 2005). Hudson had minor eruptions in $2011 \mathrm{AD}$ and $1971 \mathrm{AD}$ and a larger one in 1991 AD (Naranjo et al., 1993; Kratzmann et al., 2009; Wilson et al., 2011, 2012), as well as numerous pre-historic Holocene and Late-Glacial explosive eruptions producing tephra observed in lake cores and outcrops, including the 4,000 \pm 50 cal years BP H2 eruption, the $8,170 \pm 60$ cal years BP H1 eruption, the $17,370 \pm 70$ cal years BP Ho eruption, and multiple other small volume eruptions observed in lacustrine cores and excavated trenches (Haberle and Lumley, 1998; Naranjo and Stern, 2004; Stern et al., 2015, 2016; Weller et al., 2014, 2015). The volume of explosively erupted material, which exceeds $\sim 45 \mathrm{~km}^{3}$ (Weller et al., 2014), is not included in the estimate of the volume of its eruptive products made by Völker et al. (2011). Hudson is clearly one of the most active volcanoes in the SSVZ in terms of both the volume of material erupted and the frequency of eruptions (Weller et al., 2014, 2015).

There is significant along-strike petrochemical variability among SVZ centers. Based on whole rock chemical analysis of the southern SVZ volcanoes, López-Escobar et al. (1993, 1995a) identified petrochemically distinct basalts and basaltic andesites which they termed Type-1 and Type-2 basalts. Type-1, depleted, or Low Abundance (LA) basalts, have medium to low- $\mathrm{K}_{2} \mathrm{O}$ with relatively low concentrations of large-ionlithophile elements (Fig. 3; LILE; Rb, CS, Ba, Y, Th and U), high-field-strength elements (HFSE; Ti, $\mathrm{Zr}$, Hf), and rare-earth elements (REE) compared 

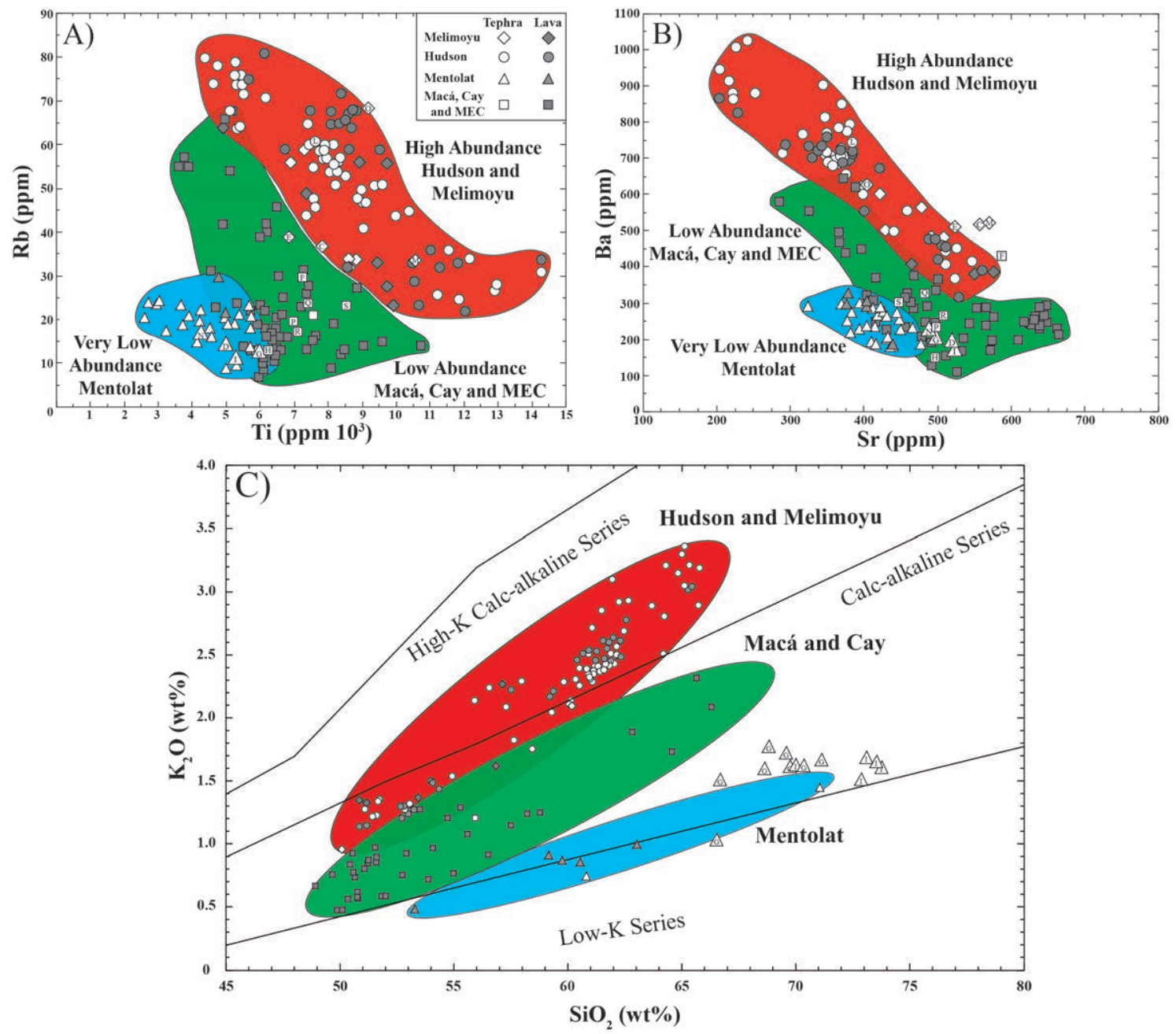

FIG. 3. A. Ti versus $\mathrm{Rb}$ and B. Sr versus Ba in parts per million (ppm) for published data of bulk tephras (white) and lavas (black) from Melimoyu, Mentolat, Macá, Cay, Hudson, and MECs (Futa and Stern, 1988; López-Escobar et al., 1993; Naranjo and Stern, 1998, 2004; D’Orazio et al., 2003; Gutiérrez et al., 2005, Kratzmann et al., 2009, 2010), and the bulk tephras from this study (white symbols with corresponding tephra nomenclature); C. $\mathrm{SiO}_{2}$ versus $\mathrm{K}_{2} \mathrm{O}$ for samples of both lava and tephra glasses from Melimoyu, Mentolat, Macá, Cay, and Hudson volcanoes and many of the minor eruptive centers in the region (Futa and Stern, 1988; López-Escobar et al., 1993; Naranjo and Stern, 1998, 2004; D’Orazio et al., 2003; Gutiérrez et al., 2005, Kratzmann et al., 2009, 2010) illustrating the distinctions of the eruptive products from these centers into the petrochemical classifications of High Abundance (HA), Low abundance (LA), and Very Low Abundance (VLA; Hickey et al., 1986, Hickey-Vargas et al., 1989; López-Escobar et al., 1993, 1995a, 1995b; Sellés et al., 2004; Stern et al., 2015; Watt et al., 2011).

to the Type-2, enriched, or High Abundance (HA) basalts. HA basalts are characterized by high- $\mathrm{K}_{2} \mathrm{O}$ with distinctively higher concentrations of HFSE, LILE, and REE (Fig. 3; López-Escobar et al., 1993, 1995a,). These petrochemical characteristics are also observed at centers further north in the SVZ (Hickey et al., 1986; Hickey-Vargas et al., 1989, 2002; López-Escobar et al., 1995b)
Among the southernmost SVZ volcanoes, Hudson, Melimoyu and the Puyuhuapi group MEC are Type2 or HA centers, while Macá, Cay, Mentolat and the Palena group MEC are Type-1 or LA volcanoes (López-Escobar et al., 1993, 1995a; D’Orazio et al., 2003; Gutiérrez et al., 2005; Carel et al., 2011; Watt et al., 2011, Stern et al., 2015, 2016; Weller et al., 2015). However, a further subdivision within the 
Type-1 or Low Abundance group has also been made to distinguish eruptive products from Mentolat, which produces lava and tephra with distinctively lower concentrations, over a wide range of $\mathrm{SiO}_{2}$ contents, of incompatible LILE, HFSE, and REE than other Type-1 LA centers (López-Escobar et al., 1993; Stern et al., 2015; Weller et al., 2015). These Very Low Abundance (VLA; Stern et al., 2015) tephras can be distinguished from the other LA centers not only by their distinctively lower concentrations of $\mathrm{K}_{2} \mathrm{O}$, LILE, HFSE, and REE (Fig. 3), but also by the abundance of hydrous phases such as amphibole (Fig. 4) and biotite which are uncommon or absent in the eruptive products from the other Type-1 LA centers of the SSVZ (Watt et al., 2011; Weller et al., 2015; Stern et al., 2016). Mentolat lavas (López-Escobar et al., 1993) and tephras (Naranjo and Stern, 2004) are similar to other VLA-type centers further to the north such as Huequi (Watt et al., 2011), Calbuco (López-Escobar et al., 1995b; Hickey-Vargas et al., 1995) and Nevado de Longaví (Sellés et al., 2004; Rodríguez et al., 2007), which also produce lavas and tephras with VLA-type petrochemical characteristics such as low- $\mathrm{K}_{2} \mathrm{O}$, LILE, HFSE, and REE compared to the volcanic products from other centers, and have amphibole as an abundant phenocryst phase.

Source volcano identification from previous tephrochonologic studies done in the southernmost SVZ were based on the comparison of either major and/or trace element analysis of published whole rock, tephra glass and bulk tephra chemical analysis (Haberle and Lumley, 1998; Naranjo and Stern, 1998, 2004; Carel et al., 2011; Stern et al., 2015,
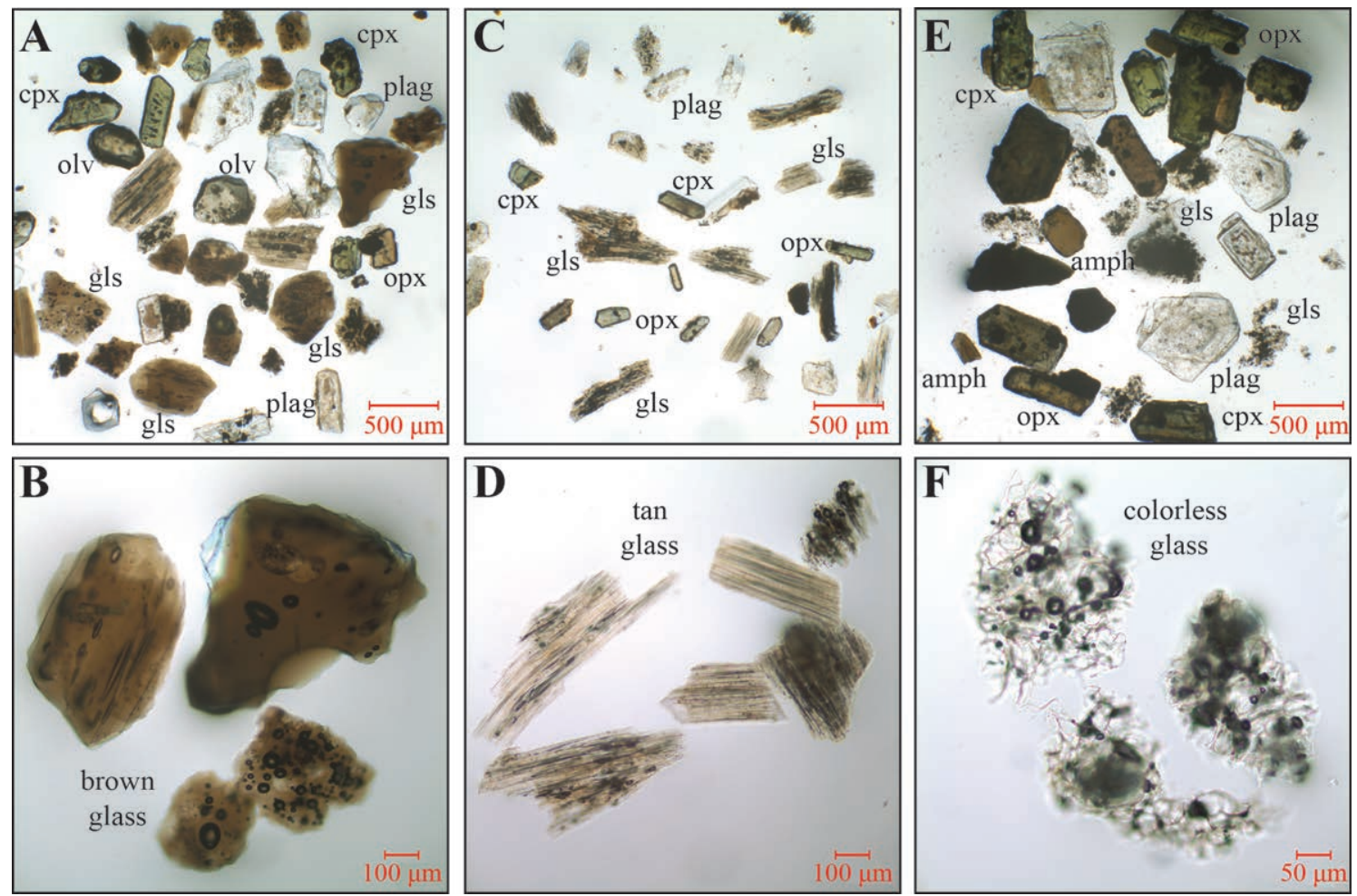

FIG. 4. Photomicrographs, of samples from the LLM core, showing representative features of the petrochemically distinct types of tephra from the different source volcanoes. A-B. Melimoyu derived MEL2 tephra containing brown to dark brown glass with vesicles that are generally circular but also containing a smaller proportion of glass with elongated vesicles. Abundant plagioclase occurs with less abundant clino- and orthopyroxene and olivine; C-D. Hudson-derived tephra containing light brown to tan glass with elongated cylindrical vesicles and phenocrysts of orthopyroxene, clinopyroxene, plagioclase but lacking amphibole and olivine; E-F. Mentolat derive (tephra I) containing colorless glass with circular vesicles, abundant phenocryst of plagioclase, clinopyroxene, orthopyroxene, and amphibole. 
2016; Weller et al., 2014, 2015). These studies demonstrated that regionally widespread tephra are derived from explosive eruptions of Melimoyu, Mentolat, Macá, and Hudson, and that bulk tephra trace element analysis preserve the high- (HA), low(LA), and very low- (VLA) abundance characteristics necessary for correlation among and source volcano identification of tephras from these centers. The same methodology is used here to chemically distinguish between the different tephra deposits, identify potential source volcanoes, and correlate the tephra from the lower Río Cisnes valley with other tephra previously identified in outcrop and in lake cores from the region (Naranjo and Stern, 1998, 2004; Stern et al., 2015, 2016; Weller et al., 2014, 2015).

\section{Methods}

Cores from the lakes were taken using a modified Livingston piston corer until the sediments reflected a transition from predominately organic rich lacustrine sediments to finely laminated glacial-lacustrine clays and sands. Transmitted x-ray images were taken of the cores to help in identification of the tephra deposits (Fig. 2). The white layers, or denser lithologies, are typically tephra deposits except in the deeper portions of the cores which includes the fine-grained glacial-lacustrine clays and sands. The dark material is the less-dense organic rich lacustrine sediments the tephra are preserved within.

The tephra deposits were removed from the core with a knife, and washed in water to remove the clay fraction and organic matter. A portion of the deposit was examined using a petrographic microscope to describe features such as tephra glass color, vesicles abundance and morphology, as well as to determine the abundance and identity of mineral phases (Fig. 4). Another bulk portion of the deposit was powdered in a moly-tungsten shatter box, dissolved in a mixture of $\mathrm{HF}$ and $\mathrm{HNO}_{3}$ for trace element analysis using an ELAN D CR Inductively coupled plasma mass spectrometer (ICP-MS). At the concentration level within these tephra, trace-element compositions are accurate within $\pm 10 \%$ based on repeat analyses of internal and external standards with known compositions (Saadat and Stern, 2011).

Strontium isotopic ratios (Fig. 5) were measured on a Finnigan-Mat 261 four-collector static Thermal

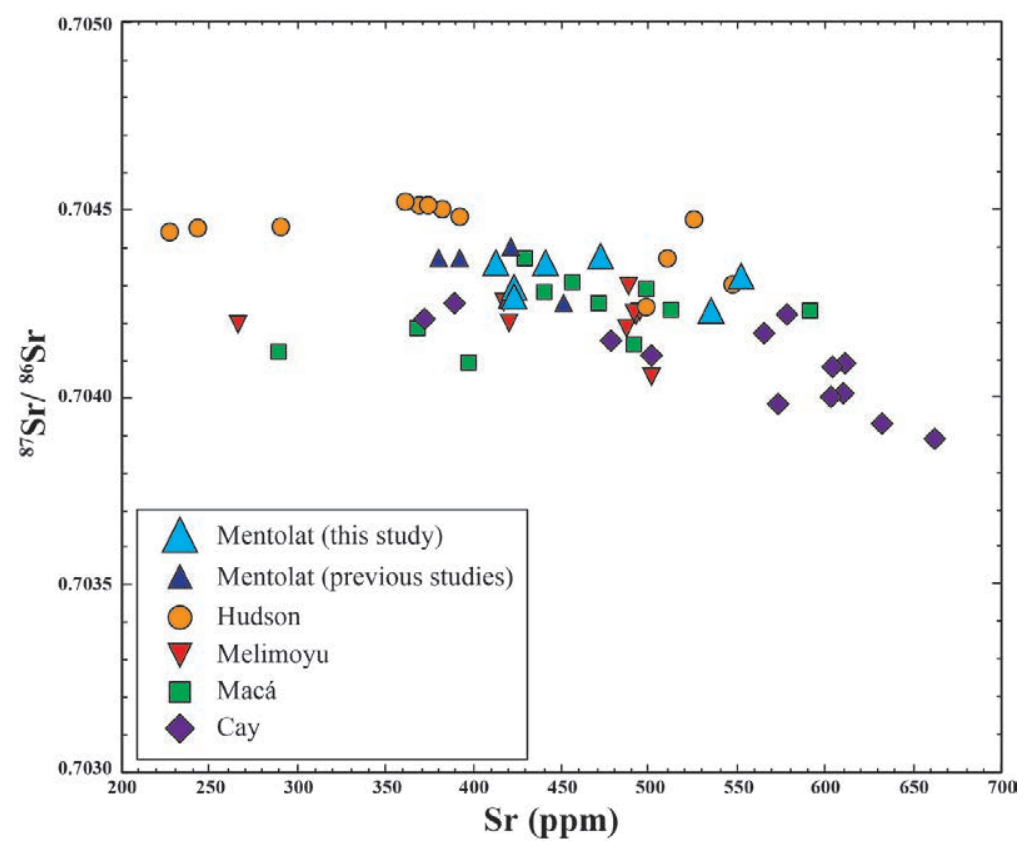

FIG. $5 .{ }^{87} \mathrm{Sr} /{ }^{86} \mathrm{Sr}$ isotope ratios versus Sr content for lavas and tephra of Melimoyu, Mentolat, Macá, Cay, and Hudson volcanoes (Notsu et al., 1987; Futa and Stern, 1988; D’Orazio et al., 2003; Weller et al., 2014). 
Ionization Mass Spectrometer. Powdered samples were dissolved in $\mathrm{HF}$ and $\mathrm{HClO}_{3}$. Based on replicate analysis of the SRM-987 standard yielded a mean ${ }^{87} \mathrm{Sr} /{ }^{86} \mathrm{Sr}$ of $0.71025 \pm 2(2 \sigma)$ and the ${ }^{87} \mathrm{Sr} /{ }^{86} \mathrm{Sr}$ were corrected to SRM-987 $=0.710299 \pm 8$. Errors of the $2 \sigma$ refer to the last two digits of the ${ }^{87} \mathrm{Sr} /{ }^{86} \mathrm{Sr}$ ratio. Further details of the analytical procedure are outlined in Farmer et al. (1991).

Major element compositions of the hand-picked white to light grey pumice lapilli were determined using a Jeol JXA-733 Electron Microprobe that was operating at $15 \mathrm{KV}$ accelerating potential with a
$5 \mathrm{nA}$ probe current. A defocused beam was used to obtain the analysis on the glasses.

New radiocarbon age determinations as well as the age of previously identify explosive eruptions observed in outcrop and in lake cores from the region, control the chronology of the cores (Fig. 6; Table 1; Naranjo and Stern, 2004; De Porras et al., 2012, 2014). AMS radiocarbon ages were determined on organic matter and converted to calendar years before present (cal yrs BP) by applying the ShCal13 curve (Hogg et al., 2013) to the CALIB 7.0.4 program (Stuiver et al., 1998, 2013).

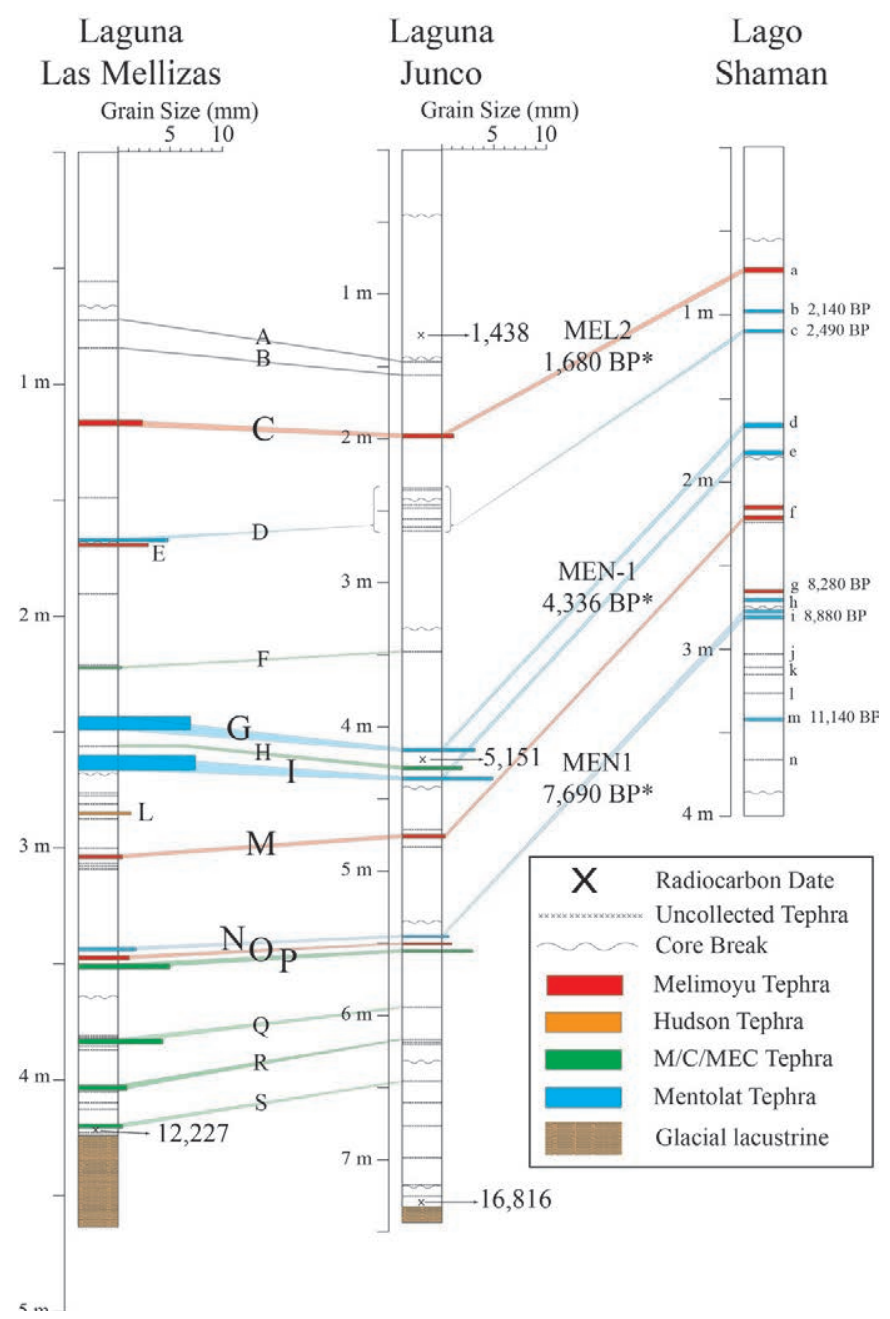

FIG. 6. Composite stratigraphic section from Laguna Las Mellizas, Laguna Junco, and Lago Shaman (De Porras et al., 2012; Stern et al., 2015) showing the correlations for tephras A-S and the maximum grain size from each tephra sampled. Note the different length scales for each lake core. These correlations include previously identified explosive eruptions observed in outcrop, including the MEN-1 (Mella et al., 2012) and the older MEN1 (Naranjo and Stern, 2004; Stern et al., 2016) eruptions of Mentolat volcano and the MEL2 eruption of Melimoyu volcano (Naranjo and Stern, 2004). 


\section{Results}

\subsection{General}

A summary of the stratigraphic information for each tephra layer is presented in table 1 . The tephra deposits that are correlative between the lake core because of their similar petrochemistry and stratigraphic relationship are named from A to S in chronologic order (Fig. 2). Some of the tephras were not sampled, such as tephra A and B from LLM because of their small size $(<1 \mathrm{~cm})$ but can be correlated to tephra in the other lake cores such as Lago Shaman based on the stratigraphic relations between the cores. Table 2 presents a description of each of the tephra sampled including the color and vesicle morphology of the most abundant glass type, abundance of phenocryst phases, maximum grain size. A classification as either HA, LA or VLA based on the petrography and the traceelement contents of each tephra, are presented in tables 3 and 4 . Table 5 presents tephra glass majorelements compositions for pumice grains from the two thickest and coarsest tephra observed in the LLM core (tephra G and I) and table 6 presents the strontium isotope ratios for the tephra I of the LLM lake core and other proximal, medial and distal Mentolat derived tephras.

TABLE 2. PETROGRAPHIC FEATURES OF THE TEPHRA.

Laguna Las Mellizas (LLM)

\begin{tabular}{|c|c|c|c|c|c|c|c|c|c|c|c|}
\hline \multirow[b]{2}{*}{ Tephra } & \multicolumn{6}{|c|}{ Phenocryst } & \multicolumn{4}{|c|}{ Glass } & \multirow[b]{2}{*}{ Max Grain Size (mm) } \\
\hline & Oliv & Plag & Cpx & Opx & Amph & Bio & Color & Vesicles & Morph. & Microlites & \\
\hline $\mathrm{C}$ & $\mathrm{XX}$ & $\mathrm{XXX}$ & $\mathrm{XX}$ & $\mathrm{X}$ & - & - & $\mathrm{Br}$ & $\mathrm{XX}$ & Circular & $\mathrm{XX}$ & 2,2 \\
\hline $\mathrm{D}$ & - & XXX & $\mathrm{XX}$ & $\mathrm{XX}$ & $\mathrm{XX}$ & - & $\mathrm{C}$ & $\mathrm{XX}$ & Circular & - & 4,8 \\
\hline $\mathrm{E}$ & $\mathrm{X}$ & XXX & $\mathrm{XX}$ & $\mathrm{X}$ & $\mathrm{X}$ & - & $\mathrm{DBr}$ & XXX & Circular & $\mathrm{X}$ & 2,9 \\
\hline $\mathrm{F}$ & $\mathrm{X}$ & XXX & $\mathrm{X}$ & $\mathrm{X}$ & - & & $\mathrm{PBr}$ & $\mathrm{XX}$ & Circular & $\mathrm{XX}$ & 0,36 \\
\hline G & $\mathrm{X}$ & XXX & $\mathrm{XX}$ & $\mathrm{XX}$ & $\mathrm{XX}$ & - & $\mathrm{C}$ & $\mathrm{XX}$ & Circular & - & 7 \\
\hline I & $\mathrm{X}$ & XXX & $\mathrm{XX}$ & $\mathrm{XX}$ & $\mathrm{XX}$ & - & $\mathrm{C}$ & $\mathrm{XX}$ & Circular & - & 7,5 \\
\hline $\mathrm{L}$ & - & $\mathrm{XX}$ & $\mathrm{XX}$ & $\mathrm{XX}$ & - & - & $\mathrm{T}$ & XXX & Elongate & - & 1,2 \\
\hline M & - & $\mathrm{XX}$ & $X$ & $X$ & $X$ & $X$ & $\mathrm{DBr}$ & XXX & Elongate & XXX & 0,45 \\
\hline $\mathrm{N}$ & $\mathrm{X}$ & XXX & $X X$ & $\mathrm{XX}$ & $\mathrm{XX}$ & - & $\mathrm{C}$ & $\mathrm{XX}$ & Circular & - & 1,7 \\
\hline $\mathrm{O}$ & - & $\mathrm{XX}$ & $\mathrm{XX}$ & $\mathrm{X}$ & - & - & $\mathrm{DBr}$ & - & - & $\mathrm{XX}$ & 1 \\
\hline $\mathrm{P}$ & $\mathrm{XX}$ & XXX & XXX & $\mathrm{X}$ & $\mathrm{X}$ & - & $\mathrm{DBr}$ & - & - & $\mathrm{X}$ & 5 \\
\hline $\mathrm{Q}$ & $\mathrm{X}$ & XXX & XXX & $\mathrm{X}$ & $\mathrm{X}$ & - & Blk & - & - & - & 4,3 \\
\hline $\mathrm{R}$ & - & XXX & $\mathrm{XX}$ & $\mathrm{X}$ & - & $\mathrm{X}$ & Blk & - & - & $\mathrm{X}$ & 0,9 \\
\hline $\mathrm{S}$ & $\mathrm{X}$ & XXX & $\mathrm{XX}$ & $\mathrm{X}$ & $\mathrm{X}$ & - & Or & $\mathrm{XX}$ & Circular & $X X$ & 0,4 \\
\hline
\end{tabular}

Laguna Junco (LJU)

\begin{tabular}{cccccccccccc}
\hline & \multicolumn{1}{c}{ Phenocryst } & \multicolumn{1}{c}{ Glass } & \\
\cline { 2 - 9 } Tephra & Oliv & Plag & Cpx & Opx & Amph & Bio & Color & Vesicles & Morph. & Microlites & Max Grain Size (mm) \\
\hline C & XX & XXX & XX & X & - & - & Br & XX & Circular & XX & 1,2 \\
G & X & XXX & XX & XX & XX & - & C & XX & Circular & - & 3,2 \\
H & X & XXX & X & X & X & - & DBr & XXX & Elongate & XXX & 2 \\
I & X & XXX & XX & XX & XX & - & C & XX & Circular & - & 5 \\
M & - & XX & X & X & X & X & DBr & XXX & Elongate & XXX & 0,25 \\
N & X & XXX & XX & XX & XX & - & C & XX & Circular & - & 0,7 \\
O & - & XX & XX & X & - & - & DBr & - & - & XX & 1 \\
P & XX & XXX & XXX & X & X & - & DBr & - & - & X & 3 \\
\hline
\end{tabular}

Color: Pale (P), Dark (D), Tan (T), Brown (Br), Orange (Or), Colorless (C), Black (Blk).

Abundance: XXX Abundant; XX Moderate; X Rare; - None. 
TABLE 3. TRACE-ELEMENT CONTENTS IN PART-PER-MILLION (PPM) OF TEPHRA FROM LAGUNA LAS MELLIZAS CORE.

\begin{tabular}{|c|c|c|c|c|c|c|c|c|c|c|c|c|c|c|}
\hline Lake & LLM & LLM & LLM & LLM & LLM & LLM & LLM & LLM & LLM & LLM & LLM & LLM & LLM & LLM \\
\hline Section & $\mathbf{T} 2$ & $\mathbf{T} 2$ & T3 & T3 & T3 & T3 & T4 & T4 & T4 & T4 & T4 & T5 & T5 & T5 \\
\hline Depth & $46-49$ & 94-96 & $0-3$ & $49.5-50$ & 71-77 & $86-92$ & $15-15.5$ & $33.5-34.5$ & $67-68$ & $71-72$ & $74-76$ & $19-21$ & $35-37$ & $51-52$ \\
\hline Source & Melimoyu & Mentolat & Melimoyu & $\mathbf{M} / \mathbf{C} / \mathbf{M}$ & Mentolat & Mentolat & Hudson & Melimoyu & Mentolat & Melimoyu & $\mathbf{M} / \mathbf{C} / \mathbf{M}$ & $\mathbf{M} / \mathbf{C} / \mathbf{M}$ & $\mathbf{M} / \mathbf{C} / \mathbf{M}$ & $\mathbf{M} / \mathbf{C} / \mathbf{M}$ \\
\hline $\begin{array}{l}\text { Tephra } \\
\text { Name }\end{array}$ & C, MEL2 & D & $\mathbf{E}$ & $\mathbf{F}$ & G, MEN-1 & I & $\mathbf{L}$ & $\mathbf{M}$ & N, MEN1 & O & $\mathbf{P}$ & $\mathbf{Q}$ & $\mathbf{R}$ & $\mathbf{S}$ \\
\hline $\begin{array}{c}\text { Chemical } \\
\text { Type }\end{array}$ & HA & VLA & HA & LA & VLA & VLA & HA & HA & VLA & HA & LA & LA & LA & LA \\
\hline Lab \# & DW15-22 & DW15-23 & DW15-24 & DW15-25 & DW15-26 & DW15-27 & DW15-28 & DW15-29 & DW15-30 & DW15-31 & DW15-32 & DW15-33 & DW15-34 & DW15-35 \\
\hline $\mathbf{T i}$ & 7,237 & 4,962 & 6,816 & 7,200 & 5,734 & 5,057 & 7,568 & 10,345 & 4,333 & 9,072 & 6,991 & 7,354 & 7,032 & 8,489 \\
\hline $\mathbf{V}$ & 239 & 242 & 249 & 310 & 297 & 249 & 163 & 343 & 206 & 207 & 364 & 214 & 274 & 276 \\
\hline $\mathrm{Cr}$ & 51 & DL & 35 & 94 & 17 & DL & DL & 19 & DL & DL & 30 & DL & 19 & DL \\
\hline Mn & 1,227 & 1,504 & 1,267 & 1,141 & 1,772 & 1,489 & 1,143 & 1,346 & 1,498 & 1,288 & 1,263 & 1,228 & 1,113 & 959 \\
\hline Co & 64 & 34 & 55 & 53 & 47 & 33 & 58 & 55 & 39 & 37 & 51 & 26 & 39 & 29 \\
\hline $\mathbf{N i}$ & 60 & 45 & 53 & 65 & 46 & 42 & 36 & 44 & 36 & 33 & 46 & 36 & 38 & 34 \\
\hline $\mathrm{Cu}$ & 72 & 43 & 63 & 104 & 32 & 19 & 136 & 181 & 82 & 113 & 87 & 55 & 180 & 326 \\
\hline $\mathrm{Zn}$ & 136 & 126 & 135 & 120 & 121 & 121 & 146 & 159 & 123 & 165 & 139 & 141 & 149 & 160 \\
\hline $\mathbf{R b}$ & 38 & 13 & 38 & 29 & 12 & 9 & 60 & 33 & 16 & 68 & 18 & 23 & 16 & 23 \\
\hline $\mathrm{Sr}$ & 560 & 529 & 531 & 592 & 487 & 535 & 392 & 570 & 497 & 412 & 514 & 490 & 513 & 454 \\
\hline $\mathbf{Y}$ & 30 & 21 & 30 & 22 & 18 & 17 & 40 & 29 & 18 & 43 & 20 & 27 & 21 & 25 \\
\hline $\mathrm{Zr}$ & 245 & 93 & 246 & 140 & 94 & 67 & 383 & 212 & 114 & 329 & 81 & 150 & 86 & 126 \\
\hline $\mathbf{N b}$ & 13 & 3 & 11 & 6 & 3 & 2 & 18 & 11 & 8 & 21 & 2 & 4 & 3 & 4 \\
\hline Cs & 0.88 & 0.82 & 0.92 & 0.81 & 0.49 & 0.46 & 1.47 & 0.84 & 1.15 & 2.93 & 1.03 & 0.89 & 0.97 & 1.19 \\
\hline $\mathbf{B a}$ & 527 & 185 & 505 & 421 & 179 & 146 & 733 & 508 & 211 & 618 & 222 & 320 & 257 & 295 \\
\hline La & 29.05 & 7.96 & 28.33 & 18.69 & 9.54 & 6.94 & 41.27 & 29.1 & 8.89 & 41.25 & 8.97 & 14.19 & 9.85 & 13.66 \\
\hline $\mathrm{Ce}$ & 67.5 & 20 & 63.8 & 43 & 22.2 & 16.9 & 92 & 67.8 & 22.1 & 91.8 & 22.3 & 35 & 23.6 & 33.3 \\
\hline Pr & 7.91 & 2.74 & 7.70 & 5.24 & 2.84 & 2.22 & 11.05 & 8.26 & 2.96 & 10.95 & 2.91 & 4.61 & 3.11 & 4.20 \\
\hline Nd & 32.4 & 13.1 & 32.5 & 22.9 & 13.4 & 11.3 & 45.0 & 36.1 & 13.6 & 46.3 & 14.0 & 20.7 & 14.7 & 19.0 \\
\hline Sm & 7.63 & 3.47 & 7.30 & 5.92 & 3.28 & 2.94 & 10.01 & 8.31 & 3.43 & 10.62 & 3.83 & 5.51 & 4.00 & 5.05 \\
\hline Eu & 2.71 & 1.34 & 2.59 & 2.13 & 1.26 & 1.27 & 3.38 & 2.72 & 1.39 & 3.19 & 1.41 & 2.01 & 1.57 & 1.90 \\
\hline Gd & 10.37 & 4.87 & 10.17 & 7.50 & 4.66 & 3.81 & 13.70 & 11.18 & 4.63 & 14.38 & 5.13 & 7.65 & 5.41 & 6.70 \\
\hline Tb & 1.12 & 0.59 & 1.07 & 0.81 & 0.50 & 0.46 & 1.44 & 1.21 & 0.54 & 1.58 & 0.61 & 0.90 & 0.64 & 0.85 \\
\hline Dy & 5.92 & 3.56 & 5.66 & 4.23 & 3.06 & 2.88 & 7.27 & 5.80 & 3.27 & 8.44 & 3.55 & 5.21 & 3.83 & 4.68 \\
\hline Но & 1.04 & 0.68 & 1.01 & 0.74 & 0.54 & 0.52 & 1.35 & 1.02 & 0.61 & 1.52 & 0.73 & 0.98 & 0.75 & 0.93 \\
\hline $\mathbf{E r}$ & 3.50 & 2.26 & 3.47 & 2.63 & 1.95 & 1.84 & 4.79 & 3.32 & 2.13 & 5.04 & 2.33 & 3.15 & 2.33 & 2.91 \\
\hline $\mathrm{Tm}$ & 0.38 & 0.20 & 0.37 & 0.18 & 0.15 & 0.14 & 0.51 & 0.34 & 0.20 & 0.57 & 0.21 & 0.35 & 0.20 & 0.27 \\
\hline $\mathbf{Y b}$ & 3.18 & 2.05 & 2.90 & 2.01 & 1.72 & 1.58 & 4.13 & 2.79 & 1.99 & 4.44 & 1.98 & 2.89 & 2.16 & 2.66 \\
\hline Lu & 0.38 & 0.22 & 0.36 & 0.22 & 0.18 & 0.15 & 0.54 & 0.33 & 0.24 & 0.60 & 0.18 & 0.32 & 0.23 & 0.32 \\
\hline Hf & 5.2 & 2.3 & 5.2 & 3.2 & 2.2 & 1.6 & 8.4 & 4.7 & 5.3 & 7.5 & 2.2 & 3.8 & 2.2 & 3.4 \\
\hline $\mathbf{P b}$ & 7.7 & 4.6 & 7.9 & 5.2 & 3.8 & 3.2 & 12.8 & 8.2 & 10.3 & 14.1 & 5.9 & 7.8 & 7.3 & 11.7 \\
\hline Th & 2.3 & 0.5 & 2.2 & 1.5 & 0.6 & 0.4 & 3.6 & 2.1 & 0.5 & 5.3 & 0.7 & 1.4 & 0.8 & 1.4 \\
\hline $\mathbf{U}$ & 1.1 & 0.4 & 1.1 & 0.8 & 0.4 & 0.3 & 1.7 & 1.0 & 0.4 & 2.7 & 0.5 & 0.8 & 0.6 & 1.0 \\
\hline
\end{tabular}

DL: Detection Limit, M/C/M: Macá, Cay, or one of the MEC. 
TABLE 4. TRACE-ELEMENT CONTENTS IN PART-PER-MILLION (PPM) OF TEPHRA FROM LAGUNA JUNCO CORE.

\begin{tabular}{|c|c|c|c|c|c|c|c|c|c|}
\hline Lake & LLJ & LLJ & LLJ & LLJ & LLJ & LLJ & LLJ & LLJ & LLJ \\
\hline Section & T3 & T5 & T5 & T5 & T6 & $\mathbf{T} 7$ & $\mathbf{T} 7$ & $\mathbf{T} 7$ & T7 \\
\hline Depth & 53-55 & $71-72$ & 83.5-85 & $92-93$ & 38-39 & $10.5-11$ & $16-16.5$ & $19-20$ & $19-20$ \\
\hline Source & Melimoyu & Mentolat & $\mathbf{M} / \mathbf{C} / \mathbf{M}$ & Mentolat & Melimoyu & Mentolat & Melimoyu & $\mathbf{M} / \mathbf{C} / \mathbf{M}$ & $\mathbf{M} / \mathbf{C} / \mathbf{M}$ \\
\hline $\begin{array}{l}\text { Tephra } \\
\text { Name }\end{array}$ & C. MEL2 & G. MEN-1 & $\mathbf{H}$ & I & M & N. MEN1 & O & $\mathbf{P}$ & $\mathbf{P}$ \\
\hline $\begin{array}{c}\text { Chemical } \\
\text { Type }\end{array}$ & HA & VLA & $\mathbf{L A}$ & VLA & HA & VLA & HA & LA & LA \\
\hline Lab \# & DW15-36 & DW15-37 & DW15-38 & DW15-39 & DW15-40 & DW15-41 & DW15-42 & DW15-43 & DW15-43D \\
\hline $\mathbf{T i}$ & 8,378 & 6,321 & 5,945 & 5,468 & 10,650 & 4,137 & 9,218 & 6,999 & 6,914 \\
\hline V & 264 & 281 & 325 & 213 & 342 & 153 & 219 & 350 & 344 \\
\hline $\mathrm{Cr}$ & 41 & 17 & 59 & DL & 20 & DL & DL & 29 & 29 \\
\hline Mn & 1,181 & 1,235 & 1,151 & 1,426 & 1,242 & 1,123 & 1,236 & 1,197 & 1,162 \\
\hline Co & 32 & 33 & 74 & 29 & 40 & 64 & 33 & 43 & 41 \\
\hline $\mathbf{N i}$ & 47 & 41 & 55 & 34 & 39 & 33 & 30 & 42 & 42 \\
\hline $\mathrm{Cu}$ & 84 & 61 & 93 & 50 & 167 & 83 & 136 & 108 & 106 \\
\hline Zn & 137 & 118 & 117 & 108 & 156 & 97 & 154 & 129 & 128 \\
\hline $\mathbf{R b}$ & 34 & 11 & 12 & 11 & 33 & 16 & 67 & 19 & 19 \\
\hline $\mathrm{Sr}$ & 574 & 519 & 504 & 525 & 579 & 497 & 411 & 493 & 498 \\
\hline Y & 29 & 21 & 18 & 20 & 32 & 21 & 43 & 21 & 21 \\
\hline $\mathbf{Z r}$ & 230 & 91 & 63 & 76 & 221 & 120 & 315 & 88 & 86 \\
\hline Nb & 10 & 3 & 3 & 2 & 16 & 5 & 20 & 3 & 3 \\
\hline Cs & 0.76 & 0.49 & 0.64 & 0.52 & 0.88 & 1.12 & 2.78 & 1.01 & 1.00 \\
\hline $\mathbf{B a}$ & 495 & 214 & 144 & 178 & 515 & 229 & 619 & 226 & 225 \\
\hline La & 29.88 & 12.88 & 6.65 & 11.68 & 31.67 & 13.45 & 41.83 & 10.99 & 10.68 \\
\hline $\mathrm{Ce}$ & 66.5 & 24.2 & 15.4 & 20.9 & 72.1 & 27.9 & 90.2 & 23.9 & 23.5 \\
\hline $\operatorname{Pr}$ & 8.39 & 3.73 & 2.30 & 3.50 & 9.05 & 4.42 & 11.18 & 3.40 & 3.38 \\
\hline Nd & 35.5 & 16.4 & 11.0 & 15.6 & 38.6 & 18.7 & 47.3 & 16.1 & 14.9 \\
\hline $\mathrm{Sm}$ & 7.78 & 4.15 & 3.12 & 3.86 & 8.71 & 4.44 & 10.96 & 4.35 & 4.16 \\
\hline Eu & 2.63 & 1.49 & 1.10 & 1.48 & 3.00 & 1.58 & 3.24 & 1.52 & 1.48 \\
\hline Gd & 10.51 & 5.42 & 4.28 & 5.29 & 11.93 & 5.65 & 14.69 & 5.64 & 5.69 \\
\hline $\mathbf{T b}$ & 1.12 & 0.62 & 0.50 & 0.60 & 1.32 & 0.72 & 1.69 & 0.65 & 0.64 \\
\hline Dy & 5.62 & 3.76 & 3.07 & 3.78 & 6.46 & 4.03 & 8.22 & 3.92 & 3.91 \\
\hline Ho & 1.01 & 0.70 & 0.61 & 0.70 & 1.17 & 0.73 & 1.55 & 0.73 & 0.74 \\
\hline $\mathbf{E r}$ & 3.57 & 2.41 & 1.88 & 2.16 & 3.74 & 2.41 & 5.11 & 2.43 & 2.37 \\
\hline $\mathbf{T m}$ & 0.36 & 0.20 & 0.16 & 0.21 & 0.38 & 0.22 & 0.55 & 0.24 & 0.24 \\
\hline $\mathbf{Y b}$ & 2.94 & 2.01 & 1.72 & 2.14 & 3.14 & 2.2 & 4.44 & 2.08 & 2.15 \\
\hline Lu & 0.35 & 0.23 & 0.18 & 0.22 & 0.39 & 0.26 & 0.58 & 0.21 & 0.21 \\
\hline Hf & 5.1 & 2.3 & 1.6 & 2.1 & 7.9 & 3.2 & 7.4 & 2.3 & 2.3 \\
\hline $\mathbf{P b}$ & 8.0 & 4.3 & 4.4 & 4.2 & 8.9 & 7.0 & 14.7 & 6.8 & 6.6 \\
\hline Th & 2.3 & 0.6 & 0.4 & 0.4 & 2.3 & 0.6 & 5.2 & 0.8 & 0.8 \\
\hline $\mathbf{U}$ & 1.1 & 0.5 & 0.9 & 0.7 & 1.3 & 1.1 & 2.6 & 0.9 & 0.9 \\
\hline
\end{tabular}

DL: Detection Limit; M/C/M: Macá, Cay or one of the MEC. 
TABLE 5. MAJOR ELEMENT COMPOSITIONS (WT\%) OF TEPHRA GLASS FROM TEPHRAS G AND I.

\begin{tabular}{|c|c|c|c|c|c|c|c|c|}
\hline Lake & LLM & LLM & LLM & LLM & LLM & LLM & LLM & LLM \\
\hline Depth (cm) & $71-77$ & 71-77 & $71-77$ & $71-77$ & $71-77$ & $71-77$ & $71-77$ & $71-77$ \\
\hline Tephra & G & G & G & G & G & G & G & G \\
\hline Pumice & $\# 1$ & $\# 2$ & $\# 3$ & $\# 4$ & $\# 5$ & \#6 & $\# 7$ & $\# 8$ \\
\hline $\mathrm{SiO}_{2}$ & 65.09 & 68.34 & 64.85 & 68.53 & 67.29 & 67.58 & 69.22 & 68.83 \\
\hline $\mathrm{TiO}_{2}$ & 0.99 & 0.96 & 0.64 & 0.92 & 1.02 & 0.97 & 0.63 & 0.64 \\
\hline $\mathrm{Al}_{2} \mathrm{O}_{3}$ & 14.55 & 14.63 & 18.35 & 15.47 & 15.27 & 14.07 & 15.3 & 17.49 \\
\hline $\mathrm{FeO}$ & 6.16 & 4.22 & 2.75 & 4.03 & 4.92 & 5.32 & 3.26 & 3.16 \\
\hline $\mathrm{MnO}$ & 0.16 & 0.28 & 0.13 & 0 & 0.15 & 0.12 & 0.41 & 0.2 \\
\hline $\mathrm{MgO}$ & 2.05 & 1.14 & 0.73 & 1.34 & 1.48 & 1.79 & 0.99 & 1.00 \\
\hline $\mathrm{CaO}$ & 4.5 & 3.48 & 5.83 & 4.09 & 4.17 & 4.04 & 2.77 & 3.15 \\
\hline $\mathrm{Na}_{2} \mathrm{O}$ & 4.74 & 4.53 & 5.38 & 3.72 & 3.59 & 4.07 & 4.57 & 3.74 \\
\hline $\mathrm{K}_{2} \mathrm{O}$ & 1.46 & 1.72 & 0.91 & 1.47 & 1.57 & 1.78 & 1.6 & 1.59 \\
\hline $\mathrm{P}_{2} \mathrm{O}_{5}$ & 0.24 & 0.34 & 0.24 & 0.24 & 0.28 & 0.16 & 0.29 & 0.16 \\
\hline Total & 99.92 & 99.65 & 99.81 & 99.79 & 99.74 & 99.89 & 99.66 & 99.96 \\
\hline Lake & LLM & LLM & LLM & LLM & LLM & LLM & LLM & L. Edita ${ }^{1}$ \\
\hline Depth (cm) & $71-77$ & 86-92 & $86-92$ & 86-92 & 86-92 & 86-92 & 86-92 & PC14 01-25 \\
\hline Tephra & G & I & I & I & I & I & I & MEN1 \\
\hline Pumice & $\# 9$ & $\# 1$ & $\# 2$ & $\# 3$ & $\# 4$ & $\# 5$ & $\# 6$ & Glass \\
\hline $\mathrm{SiO}_{2}$ & 70.31 & 68.98 & 73.04 & 72.45 & 72.38 & 73.46 & 73.01 & 71.05 \\
\hline $\mathrm{TiO}_{2}$ & 0.76 & 0.46 & 0.40 & 0.58 & 0.44 & 0.53 & 0.45 & 0.49 \\
\hline $\mathrm{Al}_{2} \mathrm{O}_{3}$ & 14.86 & 19.11 & 14.36 & 14.18 & 15.62 & 14.55 & 14.01 & 14.99 \\
\hline $\mathrm{FeO}$ & 3.72 & 2.17 & 2.26 & 2.71 & 2.54 & 2.64 & 2.68 & 2.61 \\
\hline $\mathrm{MnO}$ & 0.18 & 0.24 & 0.09 & 0.16 & 0.11 & 0.00 & 0.01 & 0.09 \\
\hline $\mathrm{MgO}$ & 1.09 & 0.63 & 0.69 & 0.76 & 0.70 & 0.67 & 0.62 & 0.68 \\
\hline $\mathrm{CaO}$ & 3.66 & 2.49 & 2.70 & 2.56 & 2.81 & 2.91 & 2.64 & 2.78 \\
\hline $\mathrm{Na}_{2} \mathrm{O}$ & 3.43 & 4.15 & 4.51 & 4.44 & 3.84 & 3.57 & 4.65 & 5.21 \\
\hline $\mathrm{K}_{2} \mathrm{O}$ & 1.65 & 1.59 & 1.63 & 1.66 & 1.45 & 1.58 & 1.62 & 1.44 \\
\hline $\mathrm{P}_{2} \mathrm{O}_{5}$ & 0.17 & 0.06 & 0.05 & 0.04 & 0.01 & 0.09 & 0.01 & 0.07 \\
\hline Total & 99.84 & 99.88 & 99.73 & 99.59 & 99.92 & 99.98 & 99.69 & 99.41 \\
\hline
\end{tabular}

${ }^{1}$ Stern et al., 2016.

TABLE 6. MENTOLAT STRONTIUM ISOTOPE RATIOS AND STRONTIUM CONTENT.

\begin{tabular}{llllccc}
\hline Material & Tephra & Locality & Sample \# & ${ }^{87} \mathbf{S r}{ }^{86} \mathbf{S r}$ & Sr (ppm) & Reference \\
\hline Tephra & I & Proximal & PC-2 & $0.704231 \pm 12$ & 535 & 1 \\
Tephra & B2 & Medial & DJW-49 & $0.704258 \pm 9$ & 422 & 2 \\
Tephra & B2 & Medial & DJW-53 & $0.704313 \pm 9$ & 555 & 2 \\
Tephra & MENo & Medial & DJW-51 & $0.704290 \pm 7$ & 422 & 2 \\
Tephra & MENo & Medial & DJW-56 & $0.704357 \pm 11$ & 439 & 2 \\
Tephra & MEN1; T-36A & Medial & PC-1 & $0.704358 \pm 10$ & 413 & 3 \\
Tephra & MEN1 & Distal & CS 1032 & $0.704375 \pm 8$ & 472 & 4 \\
Lava & - & Proximal & MEN-001 & 0.70437 & 380 & 5 \\
Lava & - & Proximal & MEN-002 & 0.7044 & 421 & 5 \\
Lava & - & Proximal & MEN-003 & 0.70425 & 451 & 5 \\
Lava & - & Proximal & MEN-004 & 0.70437 & 392 & 5 \\
Lava & - & Proximal & MEN-005 & 0.70426 & 419 & 5 \\
\hline
\end{tabular}

1: This study; 2: Weller et al., 2015; 3: Naranjo and Stern, 2004; 4: Stern et al., 2016; 5: Notsu et al., 1987. 
Similar to other observations of tephra deposits, found in outcrop and in lake sediment cores, that are derived from volcanoes of the southernmost SVZ, three petrochemically and petrographically distinct types of deposits were observed in the two new cores described here. These include High Abundance (HA), Low Abundance (LA) and Very Low Abundance (VLA) chemical types (Fig. 3; Weller et al., 2015; Stern et al., 2015, 2016; Kratzmann et al., 2009). Tephras that are HA chemical types could be derived from either Melimoyu, Hudson or the Puyuhuapi group. Previously described tephras observed near Melimoyu and Hudson attest to the active nature of these centers throughout the Holocene and during late-glacial time (Naranjo and Stern 1998, 2004; Stern et al., 2015, 2016; Weller et al., 2014, 2015). However, no tephra in this region have been previously attributed to eruptions from the Puyuhuapi group, which have abundant phenocrysts of olivine and lack orthopyroxene, amphibole, and biotite (LópezEscobar et al., 1995a). Since there are no HA type tephra from the cores in the lower Río Cisnes valley with these characteristics, we believe that none of these tephra are derived from the Puyuhuapi group.

All of the eruptions with HA chemistry are therefore thought to be derived from either Melimoyu or Hudson volcanoes. Melimoyu deposits such as the MEL2 tephra, which are heterogeneous mixtures of more primitive mafic and evolved felsic components (Naranjo and Stern, 2004), are characterized by tephra glass which is brown in color, generally containing minor amounts of rounded vesicles and variable plagioclase microlites, but also with infrequent brown glass with elongated vesicles that lack mineral microlites (Fig. 4; Stern et al., 2015). In contrast, glass from previously described Hudson eruptions (Ho, H1, H2; Weller et al., 2015; Stern et al., 2015, 2016), which are also heterogeneous mixtures, contains abundant tan to brown glass with a high proportion of elongated vesicles and lacking plagioclase microlites (Fig. 4; Kratzmann et al., 2009, 2010; Weller et al., 2014, 2015). Commonly observed phenocryst phases from both of these centers include plagioclase, clinopyroxene, orthopyroxene and less common olivine, and the felsic phase of tephra MEL1 and MEL2 from Melimoyu also both contain amphibole. The lake cores from the lower Río Cisnes valley contain several amphibole- and biotite-bearing HA petrochemical type deposits that are similar petrographically to the MEL2 tephra and contain dark brown glass with a high abundance of microlites and minor rounded vesicles. These tephras are attributed to eruptions of Melimoyu volcano since amphibole has never been reported for Hudson (López-Escobar et al., 1993; Gutiérrez et al., 2005; Kratzmann et al., 2009, 2010; Weller et al., 2014, 2015). Additionally, tephra produced from Melimoyu, which is located only $\sim 50 \mathrm{~km}$ to the northwest of LLM, would be expected to be thicker and coarser than tephras from Hudson, which is $\sim 150 \mathrm{~km}$ to southwest of this lake (Fig. 1). One thin, fine-grained tephra (tephra L in LLM) with abundant tan volcanic glass with elongated vesicles, phenocryst of plagioclase, clino- and orthopyroxene, but lacking hydrous phases, is tentatively attributed to an eruption of Hudson volcano (Fig. 6; Table 1).

All lavas (López-Escobar et al., 1993) and tephra (Naranjo and Stern, 2004; Stern et al., 2015, 2016; Weller et al., 2015) from Mentolat volcano have VLA-type chemistry (Fig. 3) and are characterized by phenocryst assemblages rich in plagioclase, clino- and orthopyroxene, amphibole, and tephra glass which is generally colorless with circular vesicles and no mineral microlites (Fig. 4). All of the tephra with VLA chemistry (Tables 3 and 4), containing colorless volcanic glass with circular vesicles (Fig. 4) and abundant phenocryst phases such at plagioclase, two pyroxenes, and amphibole, which are similar in appearance and chemistry to the MEN1 eruption of Mentolat (Naranjo and Stern, 2004; Stern et al., 2016), are attributed to explosive eruptions of Mentolat volcano.

All previous published analysis of lavas and tephra from Macá, Cay, Palena group and many of the MEC located along the LOFZ are Low Abundance (LA) chemical types. The LA-type tephra are diverse in their glass color and morphology, but in general they consist of dark brown glass containing few circular vesicles and abundant mineral microlites which is similar in color and morphology to the MAC1/ D3 tephra of Macá (Weller et al., 2015). Common phenocryst include plagioclase, clinopyroxene, with minor olivine, orthopyroxene and no or only a very small amount of amphibole or biotite. These tephra deposits, with LA-character, brown glass but lacking colorless glass and abundant amphibole, are not assigned a specific source volcano, but may be derived from Macá, Cay, Palena group or one of the many other MEC within the region. In some cases, the petrochemical fields defined by eruptive products from Mentolat and the other LA-type centers 
overlap (Fig. 3). However, none of the LA-type deposits contain colorless microlite-free volcanic glass with circular vesicles nor are they rich in amphibole phenocrysts, and therefore can be distinguished from the Mentolat derived VLA-type amphibole- and colorless felsic glass-bearing deposits.

Correlation of the deposits in the lower Río Cisnes Valley with the tephra from Lago Shaman (Table 1; Fig. 6) was done by the comparison of the petrochemistry and the stratigraphic relations between the cores.

\subsection{Tephra A and B}

Tephra A and B are the youngest samples observed in both LLM and LJU but were not collected from either core. They are thin $(<1 \mathrm{~cm})$ deposits and occur in similar stratigraphic relation in both cores. These deposits, which do not occur in Lago Shaman (Fig. 6), are both $>1,440$ cal yrs BP as indicated by a new age determination from LJU.

\subsection{Tephra C}

Tephra $\mathrm{C}$ occurs as a $4 \mathrm{~cm}$ thick layer with a maximum grain size of $2.2 \mathrm{~mm}$ in the LLM core and as a $2 \mathrm{~cm}$ thick deposit with a maximum grain size of $1.2 \mathrm{~mm}$ in the LJU core. This tephra consists of brown volcanic glass with moderate to few circular vesicles and mineral microlites (Fig. 4). A less abundant type of brown glass lacking mineral microlites but with abundant elongated vesicles also occurs in this deposit (Fig. 4). Frequently observed phenocrysts include clinopyroxene, orthopyroxene, olivine, plagioclase, but not amphibole. Tephra $\mathrm{C}$ is a HA petrochemical type (Fig. 3; Tables 3 and 4) and is similar in thickness, stratigraphic position, age, petrology, and petrochemistry to tephra ' $a$ ' from Lago Shaman (Fig. 6; Stern et al., 2015) which was correlated with the MEL2 eruption dated at $1,680 \pm 100$ cal yrs BP in outcrop (Table 1 and Fig. 6; Naranjo and Stern, 2004) and $<1,827 \pm 40$ and $>1,743 \pm 40$ cal years BP in Lago Shaman and Mallín El Embudo respectively (Stern et al., 2015).

\subsection{Tephra D}

Tephra $\mathrm{D}$ is a $2 \mathrm{~cm}$ thick deposit with a maximum grain size of $4.8 \mathrm{~mm}$ observed only in LLM core. Tephra D is a VLA petrochemical type deposit
(Fig. 3; Table 3) characterized by colorless volcanic glass with circular vesicles, and no mineral microlites. Phenocryst phases include abundant plagioclase with concentric chemical zonation, clinopyroxene, orthopyroxene, and amphibole (Table 2). Tephra D is similar petrochemically to tephra derived from Mentolat observed in outcrop and in lake cores near Coyhaique (Weller et al., 2015), Cochrane (Stern et al., 2016) and in Lago Shaman (Stern et al., 2015). Thus, tephra $\mathrm{D}$ is considered to be derived from a small to medium explosive eruption of Mentolat volcano. Based on the petrochemistry, petrology, and stratigraphic position, we correlate this deposit with tephra 'c' from Lago Shaman, which is also thought to be derived from Mentolat (Table 1; Fig. 6; De Porras et al., 2012; Stern et al., 2015).

\subsection{Tephra $E$}

Tephra E is a $3 \mathrm{~cm}$ thick, HA chemical type deposit with maximum grain size of $2.9 \mathrm{~mm}$ sitting directly below tephra D in LLM (Fig. 2; Table 1). Tephra E is characterized by dark brown volcanic glass with round vesicles with minor mineral microlites and abundant phenocryst of plagioclase, frequent clinopyroxene and orthopyroxene, minor olivine and lacking amphibole. Based on these characteristics, we interpret tephra $\mathrm{E}$ as having been derived from Melimoyu volcano. It is not observed in Lago Shaman.

\subsection{Tephra $F$}

Tephra $\mathrm{F}$ is a thin $<1 \mathrm{~cm}$ deposit with maximum grain size of $0.36 \mathrm{~mm}$ which was only sampled from LLM (Table 1) but can be correlated with a tephra in LJU based on the stratigraphy of the cores (Fig. 6). Tephra $\mathrm{F}$ is characterized by pale brown glass with minor circular vesicles and few plagioclase microlites. Phenocryst include abundant plagioclase with minor olivine, clino- and orthopyroxene, but no amphibole. Tephra F has LA-type chemistry and it could be derived from either Macá, Cay or one of the MECs (Fig. 3). No tephra with LA-type chemistry in the same stratigraphic position are observed in the Lago Shaman core in the upper Río Cisnes valley.

\subsection{Tephra G}

Tephra $\mathrm{G}$ is $6 \mathrm{~cm}$ thick deposit in LLM with a maximum grain size of $7 \mathrm{~mm}$, but is only $1 \mathrm{~cm}$ 
in LJU with a maximum grain size of $3.2 \mathrm{~mm}$. Tephra G is a VLA-type deposit with colorless glass and minor rounded vesicles and no mineral microlites (Fig. 3; Table 2). Phenocryst phases include abundant plagioclase, two pyroxenes, and amphibole. Thus, this tephra is likely produced by an explosive eruption of Mentolat volcano, which is dated as $<5,151$ cal years BP in LJU. We correlate this tephra with tephra 'd' from Lago Shaman (Fig. 6), and possibly with the $4,336 \pm 56$ cal years BP Mentolat tephra described by Mella et al. (2012) from near Puerto Cisnes, which they called MEN-1, but which is not the same tephra as the older MEN1 tephra described by Naranjo and Stern (2004) and Stern et al. (2016) further to the south. The glass analyses on the hand-picked white to grey pumice lapilli range from 65-70 weight percent $\mathrm{SiO}_{2}$ and straddle the division between the medium- and low- $\mathrm{K}_{2} \mathrm{O}$ fields similar to published glass analysis of other tephras from Mentolat (Fig. 3, Table 5; Stern et al., 2016).

\subsection{Tephra H}

Tephra $\mathrm{H}$ is $1.5 \mathrm{~cm}$ thick deposit collected from LJU, but present also in LLM core, and is correlated based on the stratigraphic relationship of the cores. Tephra $\mathrm{H}$ consists of dark brown microlite-free glass with elongated vesicles, abundant plagioclase, minor olivine, clino- and orthopyroxene, and amphibole (Table 2). Tephra H has LA-type chemistry and is likely derived from Macá, Cay or one of the MECs (Fig. 3).

\subsection{Tephra I}

Tephra $\mathrm{I}$ is a $6 \mathrm{~cm}$ thick tephra layer in LLM and $1 \mathrm{~cm}$ in LJU with maximum grain size of $7.5 \mathrm{~mm}$ and $5 \mathrm{~mm}$, respectively. Tephra I had abundant phenocryst of plagioclase, clinopyroxene, orthopyroxene, amphibole, minor olivine, and colorless glass with rounded vesicles and no mineral microlites (Fig. 4; Table 2). This tephra is a VLA chemical type and Mentolat volcano is its likely source. We correlate it with tephra 'e' of Lago Shaman (Figs. 3 and 6). The glass in white pumice grains from this deposit are all low- $\mathrm{K}_{2} \mathrm{O}$ glasses which range in $\mathrm{SiO}_{2}$ content from 69-73 weight percent and are similar to published analysis of glasses from other distal Mentolat derived tephra
(Fig. 3, Table 5; Stern et al., 2016). The strontium isotopic ratios for tephra I is $0.704230 \pm 12$ (Table 6), which is similar to both the medial (T-36A; $0.704358 \pm 10$; Naranjo and Stern, 2004) and distal (Lago Edita; 0.74375 \pm 8 ; Stern et al., 2016) MEN1 tephra deposits and other medial Mentolat derived tephras (B2; 0.704313 \pm 9 and 0.704258 \pm ; MENo $0.70429 \pm 7$ and $0.704357 \pm 11$; Weller et al., 2015) and also overlaps the Sr-isotopes ratios previously reported for lavas from Mentolat volcano (Fig. 5; Notsu et al., 1987).

\subsection{Tephra $J, K$ and $L$}

Tephra L underlies tephra J and $\mathrm{K}$, which were not sampled in either core. Tephra $L$ is $0.5 \mathrm{~cm}$ thick deposit with a maximum pumice size of $1.2 \mathrm{~mm}$. Tephra L is a HA chemical type (Fig. 3 and Table 3) containing abundant tan to light brown glass with abundant vesicles that are elongated into a cylindrical shape, and lacking mineral microlites (Fig. 4). Common phenocryst include plagioclase, clinopyroxene, orthopyroxene, but not olivine or amphibole. The tephra glass, mineral phases, age, and petrochemistry are identical to tephra observed near Coyhaique (Weller et al., 2015) which are attributed to explosive Holocene eruptions of Hudson volcano. Some eruptions of Hudson, including the Phase 1 of the 1991 Hudson eruption (Kratzmann et $a l ., 2009$ ) and the H2 eruption (Naranjo and Stern, 1998) were dispersed to the north and the northeast, respectively. We tentatively attribute tephra $\mathrm{L}$ to a Holocene eruption of Hudson volcano that was dispersed predominately to the north. Tephra $\mathrm{L}$ is not observed in LJU or in Lago Shaman.

\subsection{Tephra M}

Tephra M is observed in LLM and LJU where it occurs as a $1 \mathrm{~cm}$ deposit in both cores with maximum grain size of $0.45 \mathrm{~mm}$ and $0.25 \mathrm{~mm}$ respectively (Table 2). Tephra M is a HA chemical type consisting of dark brown glass with few circular vesicles and abundant mineral microlites (Fig. 3). Phenocrysts include minor plagioclase, clinopyroxene, orthopyroxene, and a small amount of amphibole and biotite (Table 2). We attribute this tephra to Melimoyu volcano. No amphibole- or biotite-bearing tephra with HA chemistry occurs in the same stratigraphic position in Lago Shaman. 


\subsection{Tephra $N$}

Tephra $\mathrm{N}$ occurs in both LLM and LJU where it occurs as a $1 \mathrm{~cm}$ thick deposit in each core with grain sizes of 1.7 and $0.7 \mathrm{~mm}$ respectively. From both cores, tephra $\mathrm{N}$ is characterized by colorless tephra glass with circular vesicles, and lacking mineral microlites, abundant phenocrysts of plagioclase, clinopyroxene, orthopyroxene, and amphibole (Table 2). This tephra has a VLA-type chemistry and was likely derived from Mentolat volcano (Fig. 3). Tephra ' $\mathrm{i}$ ' is a VLA-type tephra in the same stratigraphic position and is tentatively correlated with tephra N of the LLM and LJU cores (Fig. 6). The age, petrochemistry, and petrographic features are similar to the previously observed MEN1 eruption from lake cores near Cochrane (Stern et al., 2016) and in an outcrop southeast of Mentolat (94T-36A; Naranjo and Stern, 2004) which has been dated at $7,690 \pm 60$ cal years BP.

\subsection{Tephra O}

Tephra $\mathrm{O}$ occurs as a $1 \mathrm{~cm}$ and a $0.5 \mathrm{~cm}$ thick deposit in LLM and LJU cores and has a maximum gain size of $1 \mathrm{~mm}$ from both lake cores. Tephra $\mathrm{O}$ is a HA chemical type deposit (Fig. 3) with brown glass with few rounded vesicles and few mineral microlites, frequent plagioclase, and minor pyroxenes and olivine (Fig. 4; Table 2). This tephra is similar petrochemically and petrographically to tephras $\mathrm{C}$ and $\mathrm{E}$ and thus we source this eruption from Melimoyu volcano.

\subsection{Tephra $P$}

Tephra $\mathrm{P}$ is a LA chemical type deposit observed in both LLM and LJU as a $2 \mathrm{~cm}$ and $1 \mathrm{~cm}$ thick deposit with a maximum grain size of $5 \mathrm{~mm}$ and $3 \mathrm{~mm}$ respectively (Fig. 3). Tephra P consists of dark brown volcanic glass lacking vesicles or microlites (Table 2). Phenocrysts include abundant plagioclase, frequent clinopyroxene, olivine, minor orthopyroxene, and amphibole (Table 2). Tephra P may have been derived from Macá, Cay or one of the MECs.

\subsection{Tephra Q}

Tephra Q occurs as a $2 \mathrm{~cm}$ thick deposit with a maximum grain size of $4.3 \mathrm{~mm}$ from LLM. This tephra is characterized by LA type chemistry, black volcanic glass lacking vesicles or microlites, abundant plagioclase, clinopyroxene, minor olivine, orthopyroxene, and amphibole (Fig. 3; Table 2). Tephra Q is likely sourced from Macá, Cay or one of the MECs. Tephra $\mathrm{Q}$ is tentatively correlated to an uncollected tephra in LJU based on the stratigraphy, but no tephra occurs in Lago Shaman with similar petrology or petrochemistry.

\subsection{Tephra $R$}

Tephra R is a LA chemical type deposit (Fig. 3) observed in LLM where it occurs as a $2 \mathrm{~cm}$ thick deposit with a maximum grain size of $0.9 \mathrm{~mm}$. Tephra $\mathrm{R}$ has black glass that lacks vesicles and microlites. Observed phenocrysts include abundant plagioclase, frequent clinopyroxene, minor orthopyroxene, and biotite (Table 2). Tephra $\mathrm{R}$ is tentatively correlated to an uncollected tephra in LJU but no tephra with similar chemistry or petrology occurs in Lago Shaman core. Tephra R may have been derived from Macá, Cay or one of the MECs.

\subsection{Tephra S}

Tephra $\mathrm{S}$ is the oldest deposit sampled from the LLM core where it occurs as a $1 \mathrm{~cm}$ thick deposit with LA type chemistry (Fig. 3) and has a maximum grain size of $0.4 \mathrm{~mm}$. Tephra $\mathrm{S}$ has orange glass with few circular vesicles and abundant mineral microlites. Tephra S consists of abundant plagioclase, minor clinopyroxene, orthopyroxene, and trace amounts of green amphibole (Table 2). Tephra S many have been derived from Macá, Cay or one of the MECs. Tephra $\mathrm{S}$ is tentatively correlated to an uncollected tephra in LJU based on the stratigraphy but no tephra occurs in Lago Shaman with similar petrology or petrochemistry.

\section{Discussion and Conclusion}

Some of the tephra in the cores from LLM and LJU correspond to other tephra observed in cores taken from Lago Shaman (Fig. 6; Table 1; Stern et al., 2015), to the south near Coyhaique (Weller et al., 2015), Cochrane (Stern et al., 2016) and to tephras observed in outcrops from the region (Naranjo and Stern, 2004). Of the 14 tephra deposits sampled, four are similar petrographically and petrochemically to 
tephras previously attributed to explosive eruptions of Mentolat volcano. Four of the deposits are similar to previously described deposits from Melimoyu, one possibly from Hudson, and six may have been derived from Macá, Cay or one of the MECs located along the LOFZ or surrounding the major volcanic centers.

Mentolat derived tephra are all VLA chemical type deposits and are petrographically distinct in having colorless volcanic glass and phenocryst-rich including plagioclase, clinopyroxene, orthopyroxene, and amphibole. These deposits are thicker and coarser-grained in the LLM core consistent with their derivation from Mentolat, the geographically closest volcano to this lake. The two thickest tephra from this core (tephra G and I) have glass chemistry (Table 5), bulk trace-element chemistry, and tephra Sr-isotopic ratios (Table 6) similar to whole rock major and trace element contents and Sr-isotope ratios of lavas from Mentolat (Notsu et al., 1987; López-Escobar et al., 1993).

Melimoyu derived tephra are all HA chemical types and contain brown to dark brown glass with moderate to few circular vesicles, occasionally with minor elongated vesicles, and variable amounts of plagioclase microlites. Common phenocryst include plagioclase, two pyroxenes, olivine, and sometimes amphibole and biotite. Tephras from large explosive eruptions from Hudson are also HA chemical types but consist of tan to light brown glass with abundant elongated vesicles, phenocrysts of plagioclase, clinoand orthopyroxene but lacking amphibole or biotite. Only one of the HA tephra, tephra L from LLM core, appears similar to Hudson derived tephra. Tephra from this eruption was either never sampled from the Lago Shaman, or never reached that far northeast, although tephra from the late-glacial age Ho eruption does occur in the Lago Shaman core (Weller et al., 2014; Stern et al., 2015). Puyuhuapi group of MEC also erupted HA type basalts. However, there is no clear evidence that any of the tephra preserved in the cores from the Río Cisnes valley were derived from the Puyuhuapi group of MEC as these cones produce lavas and scoria with abundant olivine which lack orthopyroxene, amphibole, and biotite.

Unlike the tephra in Lago Shaman and Mallín El Embudo, LLM and LJU contain tephra that we attribute to eruptions from either Macá, Cay or MECs. These LA-type deposits are variable in petrography (glass color and morphology, mineral assemblages). Naranjo and Stern (2004) and Weller et al. (2015) attributed a basaltic-andesite tephra dated at $1,440 \pm 40$ cal years BP (MAC1/D3) as being sourced from Macá volcano. However there is no evidence that the MAC1 tephra was dispersed over the Río Cisnes valley, despite the presence of some LA type tephra potentially derived from older eruptions of Macá or Cay volcanoes in both LLM and LJU. These older LA type tephra may be preserved within the cores from Lago Shaman and Mallín El Embudo, but if so they were too thin $(<1 \mathrm{~cm})$ to be sampled.

These results confirm the repetitive explosive activity of Mentolat, Melimoyu and Hudson throughout the Holocene. The petrochemical data and the petrographic observations suggest that the petrochemical characteristics of the products from these centers have been relatively consistent throughout the Holocene. The majority of the deposits lie within the fields created by the previously published whole rock tephra trace-element analysis from the SSVZ centers. However, several of the deposits lie outside of those fields, but are similar petrographically and petrochemically to the other deposits attributed to those volcanoes. We suggest that these outliers are the result of the fact that these tephras are heterogeneous mixtures of both mafic and felsic components (Kratzmann et al., 2009; Scasso et al., 1994; Scasso and Carey, 2005; Weller et al., 2015). Density differences between these components are such that proximal deposits would likely have a higher proportion of dense mafic material and thus would have different bulk trace element contents than the more distal felsic component rich deposits, while still preserving the HA, LA and VLA character of the tephra.

These tephra records, and those form Lago Shaman and Mallín El Embudo, indicate that local population centers such as Puerto Cisnes could be impacted by eruptions from Mentolat, Melimoyu, and potentially one of the other centers located within the region such as Macá or Cay, which have also produced regionally widespread tephra deposits during the Holocene.

\section{Acknowledgements}

This research was supported by FONDECYT-Chile grant \#1130128. We are grateful to B. von Malapert and R. Álvarez for permission to core Laguna Junco and Laguna Las Mellizas, respectively, and to Hospital Público San Juan de Dios (La Serena) for facilities to take the digital $\mathrm{X}$-radiographs of the cores. We thank Á. Amigo for constructive comments that helped improve the final manuscript. 


\section{References}

Carel, M.; Siani, G.; Delpech, G. 2011. Tephrostratigrapy of a deep-sea sediment sequence off the south Chilean margin: New insight into the Hudson volcanic activity since the last glacial period. Journal of Volcanology and Geothermal Research 208: 99-111.

De Porras, M.E.; Maldonado, A.; Abarzúa, A.M.; Cárdenas, M.L.; Francois, J.P.; Martel-Cea, A.; Stern, C.R.; Méndez, C.; Reyes, O. 2012. Postglacial vegetation, fire and climate dynamics at Central Chilean Patagonia (Lake Shaman, $44^{\circ} \mathrm{S}$ ). Quaternary Science Reviews 50: 71-85.

De Porras, M.E.; Maldonado, A.; Quintana, F.A.; MartelCea, A.J.; Reyes, O.; Méndez, C. 2014. Environmental and climatic changes in Central Chilean Patagonia since the Late Glacial (Mallín El Embudo, 44오). Climate of the Past 10: 1063-1078.

D’Orazio, M.; Innocenti, F.; Manetti, P.; Tamponi, M.; Tonarini, S.; González-Ferrán, O.; Lahsen, A.; Omarini, R. 2003. The Quaternary calc-alkaline volcanism of the Patagonian Andes close to the Chile triple junction: geochemistry and petrogenesis of volcanic rocks from the Cay and Maca volcanoes ( $45^{\circ} \mathrm{S}$, Chile). Journal of South American Earth Sciences 16: 219-242.

Farmer, G.L.; Broxton, D.E.; Warren, R.G.; Pickthorn, W. 1991. Nd, Sr, and O isotopic variations in metaluminous ash-flow tuffs and related volcanic rocks at Timber Mountain/ Oasis Valley Caldera, Complex, SW Nevada: implication for the origin and evolution of large-volume silicic magma bodies. Contributions to Mineralogy and Petrology 109: 53-68.

Fontijn, K.; Lachowycz, S.M.; Rawson, H.; Pyle, D.M.; Mather, T.A.; Naranjo, J.A.; Moreno-Roa, H. 2014. Late Quaternary tephrostratigraphy of southern Chile and Argentina. Quaternary Science Reviews 89: 70-84.

Futa, K.; Stern, C.R. 1988. Sr and Nd isotopic and trace element compositions of orogenic Quaternary volcanic centers of the southern Andes. Earth and Planetary Science Letters 88: 253-262.

Gutiérrez, F.; Gioncada, A.; González-Ferrán, O.; Lahsen, A.; Mazzuoli, R. 2005. The Hudson volcano and surrounding monogenetic centres (Chilean Patagonia): an example of volcanism associated with ridge-trench collision environment. Journal of Volcanology and Geothermal Research 145: 207-233.

Haberle, S.G.; Lumley, S.H. 1998. Age and origin of tephras recorded in postglacial lake sediments to the west of the southern Andes, $44^{\circ} \mathrm{S}$ to $47^{\circ} \mathrm{S}$. Journal of Volcanological and Geothermal Research 84: 239-256.
Hickey, R.L.; Frey, F.A.; Gerlach, D.C. 1986. Multiple sources for basaltic arc rocks from the Southern Volcanic Zone of the Andes (34-41 $\left.{ }^{\circ} \mathrm{S}\right)$ : Trace element and isotopic evidence for contributions from subducted oceanic crust, mantle, and continental crust. Journal of Geophysical Research 91: 5963-5983.

Hickey-Vargas, R.L.; Moreno-Roa, H.; López-Escobar, L.; Frey, F.A. 1989. Geochemical variations in Andean basaltic and silicic lavas from the Villarrica-Lanín volcanic chain $\left(39.5^{\circ} \mathrm{S}\right)$ : an evaluation of source heterogeneity, fractional crystallization and crustal assimilation. Contributions to Mineralogy and Petrology 103: 361-386.

Hickey-Vargas, R.L.; Abdollahi, M.J.; Parada, M.A.; LópezEscobar, L.; Frey, F.F. 1995. Crustal xenoliths from Calbuco Volcano, Andean Southern Volcanic Zone: implications for crustal composition and magma-crust interaction. Contributions to Mineralogy and Petrology 119: 331-344.

Hickey-Vargas, R.L.; Sun, M.; López-Escobar, L.; MorenoRoa, H.; Reagan, M.K.; Morris, J.D.; Ryan J.G. 2002. Multiple subduction components in the mantle wedge: evidence from eruptive centers in the Central Southern volcanic zone, Chile. Geology 30 (3): 199-202.

Hogg, A.; Hua, Q.; Blackwell, P.; Niu, M.; Buck, C.; Guilderson, T.; Heaton, T.; Palmer, J.; Reimer, P.; Reimer, R.; Turney, C.; Zimmerman, S. 2013. SHCAL13 Southern Hemisphere Calibration, 0-50,000 years CAL BP. Radiocarbon 55 (4): 1889-1903.

Kratzmann, D.J.; Carey, S.; Scasso, R.A.; Naranjo, J.A. 2009. Compositional variations and magma mixing in the 1991 eruptions of Hudson volcano, Chile. Bulletin of Volcanology 71 (4): 419-439.

Kratzmann, D.J.; Carey, S.; Scasso, R.A.; Naranjo, J.A. 2010. Role of cryptic amphibole crystallization in magma differentiation at Hudson volcano, Southern Volcanic Zone, Chile. Contributions to Mineralogy and Petrology 159: 237-264.

López-Escobar, L.; Kilian, R.; Kempton, P.; Tagiri, M. 1993. Petrology and geochemistry of Quaternary rocks from the southern volcanic zone of the Andes between $41^{\circ} 30^{\prime}$ and $46^{\circ} 00^{\prime} \mathrm{S}$, Chile. Revista Geológica de Chile 20 (1): 33-55. doi: 10.5027/andgeoV22n2-a06.

López-Escobar, L.; Cembrano, J.; Moreno, H. 1995a. Geochemistry and tectonics of the Chilean Southern Andes basaltic Quaternary volcanism $\left(37^{\circ}-46^{\circ} \mathrm{S}\right)$. Revista Geológica de Chile 22 (2): 219-234.

López-Escobar, L.; Parada, M.A.; Hickey-Vargas, R.; Frey, F.A.; Kempton, P.D.; Moreno, H. 1995b. Calbuco Volcano and minor eruptive centres distributed along 
the Liquiñe-Ofqui Fault Zone, Chile $\left(41^{\circ}-42^{\circ} \mathrm{S}\right)$ : contrasting origin of andesitic and basaltic magma in the Southern Volcanic Zone of the Andes. Contributions to Mineralogy and Petrology 119: 345-361.

Lowe, D.J. 2011. Tephrochronology and its application: a review. Quaternary Geochronology 6: 107-153.

Mella, M.; Ramos, A.; Kraus, S.; Duhart, P. 2012. Datos tefroestratigráficos de erupciones Holocenas del Volcán Mentolat, Andes del Sur (4440’S), Chile. In Congreso Geológico Chileno, No. 13, Actas: 580-582. Antofagasta.

Miranda, C.G.; Moreno, P.I.; Vilanova, I.; Villa-Martínez, R.P. 2013. Glacial fluctuations in the Coyhaique-Balmaceda sector of central Patagonia $\left(45-46^{\circ} \mathrm{S}\right)$ during the last glacial termination. Bollettino di Geofisica 54: 268-271.

Naranjo, J.A.; Stern, C.R. 1998. Holocene explosive activity of Hudson Volcano, southern Andes. Bulletin of Volcanology 59: 291-306.

Naranjo, J.A.; Stern, C.R. 2004. Holocene tephrochronology of the southernmost part $\left(42-45^{\circ} \mathrm{S}\right)$ of the Andean Southern Volcanic Zone. Revista Geológica de Chile 31 (2): 225-240.

Naranjo, J.A.; Moreno, H.R.; Banks, N.G. 1993. La Erupción del Volcán Hudson en 1991 (46º S), Región XI, Aisén, Chile. Servicio Nacional de Geología y Minería 44: 1-50.

Notsu, K; López-Escobar, L; Onuma, N. 1987. Along-arc variation of $\mathrm{Sr}$-isotopic composition in volcanic rocks from the Southern Andes $\left(33^{\circ} \mathrm{S}-55^{\circ} \mathrm{S}\right)$. Geochemical Journal 22: 307-313.

Rodríguez, C.; Sellés, D.; Dungan, M.; Langmuir, C.; Leeman, W. 2007. Adikitic dacites formed by intracrustal crystal fractionation of water-rich parent magmas at Nevado de Longaví (36.2 ${ }^{\circ} \mathrm{S}$; Andean Southern Volcanic Zone, Central Chile). Journal of Petrology 48 (11): 2033-2061.

Saadat, S.; Stern, C.R. 2011. Petrochemistry and genesis of olivine basalts from small monogenetic parasitic cones of Bazman stratovolcano, Makran arc, southeastern Iran. Lithos 125: 609-617.

Scasso, R.A.; Corbella, H.; Tiberi, P. 1994. Sedimentological analysis of the tephra from the 12-15August 1991 eruption of Hudson volcano. Bulletin Volcanology 56: 121-132.

Scasso, R.A.; Carey S. 2005. Morphology and formation of glassy volcanic ash from the August 12-15, 1991 eruption of Hudson volcano, Chile. Latin American Journal of Sedimentology and Basin Analysis 12 (1): 3-21.

Sellés, D.; Rodríguez, A.C.; Dungan, M.A.; Naranjo, J.A.; Gardeweg, M. 2004. Geochemistry of Nevado de Longaví volcano $\left(36.2^{\circ} \mathrm{S}\right)$ : a compositionally atypical arc volcano in the Southern Volcanic Zone of the Andes. Revista Geológica de Chile 31 (2): 293-315. doi: 10.5027/andgeoV31n2-a08.
Stern, C.R. 2004. Active Andean Volcanism: its geologic and tectonic setting. Revista Geológica de Chile 31 (2): 161-206. doi: 10.5027/andgeoV31n2-a01.

Stern, C.R; de Porras M.E.; Maldonado, A. 2015. Tephrochronology of the upper Río Cisnes valley $\left(44^{\circ} \mathrm{S}\right)$, southern Chile. Andean Geology 42 (2): 173-189. doi: 10.5027/andgeoV42n2-a02.

Stern, C.R.; Moreno, P.I.; Henríquez, W.I.; Villa-Martínez, R.P.; Sagredo, E.; Aravena, J.C. 2016. Holocene tephrochronology in the area around Cochrane, southern Chile. Andean Geology 43 (1): 1-19. doi: 10.5027/andgeoV43n1-a01.

Stuiver, M.; Reimer, P.J.; Braziunas, T.F. 1998. High precision radiocarbon age calibration for terrestrial and marine samples. Radiocarbon 40 (3): 1127-1151.

Stuiver, M.; Reimer, P.J.; Reimer, R. 2013. CALIB 7.0.4. http://calib.qub.ac.uk/calib/

Vargas, G.; Rebolledo, S.; Sepúlveda, S.A.; Lahsen, A.; Thiele, R.; Townley, B.; Padilla, C.; Rauld, R.; Herrera, M.J.; Lara, M. 2013. Submarine earthquake rupture, active faulting and volcanism along the major LiquiñeOfque Fault Zone and implications for seismic hazard assessment in the Patagonian Andes. Andean Geology 40 (1): 141-171. doi: 10.5027/andgeoV40n1-a07.

Völker, D.; Kutterolf, S.; Wehrmann, H. 2011. Comparative mass balance of volcanic edifices at the southern volcanic zone of the Andes between $33^{\circ} \mathrm{S}$ and $46^{\circ} \mathrm{S}$. Journal of Volcanology and Geothermal Research 205: 114-129.

Watt, S.F.L.; Pyle, D.M.; Mather, T.A. 2011. Geology, petrology and geochemistry of the dome complex of Huequi volcano, southern Chile. Andean Geology 38 (2): 335-348. doi: 10.5027/andgeoV38n2-a05.

Weller, D.; Miranda, C.G.; Moreno, P.I.; Villa-Martínez, R.; Stern, C.R. 2014. The large late-glacial Ho eruption of the Hudson volcano, southern Chile. Bulletin of Volcanology 76: 831-849.

Weller, D.; Miranda, C.G.; Moreno, P.I.; Villa-Martínez, R.; Stern, C.R. 2015. Tephrochronology of the southernmost Andean Southern Volcanic Zone, Chile. Bulletin of Volcanology 77: 107-131.

Wilson, T.M.; Cole, J.W.; Stewart, C.; Cronin, S.J.; Johnston, D.M. 2011. Ash storms: impacts of wind-remobilised volcanic ash on rural communities and agriculture following the 1991 Hudson eruption, southern Patagonia, Chile. Bulletin of Volcanology 73: 223-239.

Wilson, T.; Cole, J.; Johnston, D.; Cronin, S.; Stewart, C.; Dantas, A. 2012. Short-and long-term evacuation of people and livestock during a volcanic crisis: lessons from the 1991 eruption of Volcán Hudson, Chile. Journal of Applied Volcanology 1: 1-11. 